\title{
One Billion Years of Earth History: Challenges of Valorizing the Outstanding Geodiversity of Southwest Germany for Sustainable Geotourism
}

\author{
Heidi Elisabeth Megerle
}

Citation: Megerle, H.E. One Billion Years of Earth History: Challenges of Valorizing the Outstanding Geodiversity of Southwest Germany for Sustainable Geotourism. Sustainability 2022, 14, 559. https:// doi.org/10.3390/su14010559

Academic Editors: Nemanja Tomić and Slobodan B. Marković

Received: 30 November 2021 Accepted: 30 December 2021 Published: 5 January 2022

Publisher's Note: MDPI stays neutral with regard to jurisdictional claims in published maps and institutional affiliations.

Copyright: (c) 2022 by the author. Licensee MDPI, Basel, Switzerland. This article is an open access article distributed under the terms and conditions of the Creative Commons Attribution (CC BY) license (https:/ / creativecommons.org/licenses/by/ $4.0 /)$.
University of Applied Forest Sciences, D-72108 Rottenburg am Neckar, Germany; megerle@hs-rottenburg.de; Tel.: +49-7472-951-243

\begin{abstract}
The German state of Baden-Württemberg boasts outstanding geo-, bio-, and archaeological diversity, and hosts two of the world's oldest geoparks. Based on this case study, we explore why the outstanding geoheritage has not been valorized to a greater extent for a lay audience and where best to strike the balance between valorization and protection, with a particular focus on recent developments including the repercussions of the COVID-19 pandemic. Our results show that the valorizing of the geopotentials is still insufficient. Better marketing can make an important contribution to regional added value, as well as - in combination with professional geo-education-a relevant contribution to raising awareness of the state's natural assets. Adequate measures to protect geotopes in a sustainable manner are crucial, notably in light of problems arising from overtourism, as thrown into sharp relief during the COVID-19 pandemic.
\end{abstract}

Keywords: geoheritage; geodiversity; archeodiversity; Baden-Württemberg; geopark Swabian Alb; COVID-19 pandemic; valorization

\section{Introduction}

Geotourism, geodiversity, and geotope protection were treated as secondary to biodiversity, nature tourism, and biological nature conservation in research, as well as in practical implementation, for a long time. Geotourism, long considered a form of niche tourism [1], has recently become a popular form of themed tourism [2-8]. Over the course of the past decade, geotourism has been one of the fastest growing branches of tourism [9], and there has been much academic debate as to its precise definition and how best to manage geoheritage $[2-8,10,11]$. The assets of geotourism span a wide spectrum of geological and geomorphological landforms, ranging from active volcanism to precambrian rock formations, karst, or glacial environments. Geotourism concentrates not only on geology, but also on a broad spectrum of topics related to the history of the earth, including vegetation, fauna, cultural landscapes, and anthropogenic features such as mines and quarries [8].

Tourism is rated as the "leading economy of the twentieth century" because of its high rates of growth and regional added value [12]. The growing importance of geotourism goes along with opportunities, especially for regions with an outstanding geoheritage [13]. On the other hand, we have to take into account the challenges and risks of valorizing sensitive geoheritage like tufa formations [14-18], especially in view of a still often insufficient geotope protection [19-22]. Therefore, it is important to raise public awareness for the importance of geotopes and their protection [11].

The German state of Baden-Württemberg shows outstanding geo-, bio-, and archaeological diversity, and possesses two of the world's oldest geoparks. On a relatively small area of $280 \mathrm{~km}$ by $210 \mathrm{~km}$, a billion years of geological history unfolds [23-26]. Such geodiversity within the radius of a day's travel is extremely rare worldwide. At the same time, Baden-Württemberg is also one of the national hot-spots of biodiversity. Numerous UNESCO heritage sites highlight this outstanding geo-, bio-, archaeological, and cultural 
diversity. Despite the global importance as the location for the automotive (Daimler, Audi, and Porsche) and metal-processing industries [27], tourism is one of the most relevant economic sectors [28]. Baden-Württemberg ranks second in Germany after Bavaria [29]. While the outstanding geoheritage and the globally significant archaeological sites have attracted scientists from all over the world for decades, this heritage is still only used to a limited extent for sustainable geotourism.

This article focuses on the great importance of regional geo- and archeoheritage in Baden-Württemberg and its value as a tourist attraction. Based on this case study, we will explore why this outstanding geoheritage has not been valorized to a greater extent for a lay audience, where best to strike the balance between valorization and protection, and offer possible solutions. Current developments in the context of the COVID-19 pandemic, as well as perspectives for post-COVID times, form an additional focus of our study. While restrictions on travel and the use of recreational facilities have led to a significant decline in the number of international tourists [30], there has been a simultaneous rediscovery of the "Heimat" (homeland), associated with a significant increase in visitors to natural areas, the latter with mostly negative repercussions for the environment [31,32].

\section{Conceptual Basis}

Dealing with geotourism includes taking into account geodiversity, geoconservation, geo-education, and the Geopark movement.

\subsection{Geodiversity}

In contrast to biodiversity, a term now also widely integrated in everyday language, the term geodiversity was first used in the 1990s to describe the diversity of abiotic natural phenomena [11]. Geodiversity is understood to mean "The natural range (diversity) of geological (rocks, minerals, fossils), geomorphological (landform, physical processes) and soil features. It includes their assemblages, relationships, properties, interpretations and systems" [11]. Previous work [13] classifies particularly valuable components of geodiversity as geoheritage. The sustainable valorization of geoheritage is the basis of sustainable geotourism.

\subsection{Geotourism}

Geotourism, long considered a form of niche tourism [1], has evolved into an indemand form of themed tourism [2-8] among others. In the last decade, geotourism even proved to be the fastest growing tourism segment [9]. Previous work [33] defines geotourism very narrowly as "tourism focused on geological features". On the other hand, the definition of [34] given for geotourism includes an extremely broad interpretation, making it difficult to distinguish geotourism from other forms of tourism such as ecotourism or nature tourism: "tourism that sustains or enhances the geographical character of a place-its environment, culture, aesthetics, heritage, and the well-being of its residents". Geotourism has been previously described as "a form of natural area tourism that specifically focuses on geology and landscape. It promotes tourism to geosites, the conservation of geodiversity and an understanding of earth sciences through appreciation and learning. This is achieved through independent visits to geological features, use of geo-trails and viewpoints, guided tours, geo-activities and patronage of geosite visitor centers" [4]. Geotourism includes not only the actual geoheritage, but also the broad spectrum of topics related to the history of the earth, including interactions with vegetation, fauna, cultural landscape, and anthropogenic uses such as the extraction of raw and building materials. Geotourism not only serves as an instrument of sustainable regional development, but must also ensure geotope protection by raising awareness through geo-education [8]. In 2011, the European Geoparks adopted the Arouca Declaration, which defines the cornerstones of the desired sustainable geotourism activities [35].The goals of sustainable geotourism are geoconservation, high-quality geotourism, benefits for the host communities, and raising awareness of the significant contributions that geotourism can make to the environment, local communities, 
and the economy [36]. In particular, UNESCO Global Geoparks represent a successful path to global sustainability by fostering the economic sustainable development of host regions through the promotion of geotourism and geo-education $[37,38]$.

In parallel with a growing number of publications on geodiversity and geotope protection over the last two decades, geotourism and the scientific debate have also developed very dynamically $([2-8,10,11,39,40]$, etc.).

Providing an overview of geotourism, the number of geotourists, and its value for the regional economy is difficult as the narrowly defined geotourism [33] is still underdeveloped, yet at the same time, many tourist activities may involve an element of geotourism [39]. In many cases, this applies to eco- and nature tourism, as well as to special forms of urban tourism [41]. Despite these definitional ambiguities, geotourism can be an important economic factor, especially for peripheral and structurally weak regions [11], can raise awareness for geo-heritage protection [4] and, with an appropriate strategy, can promote geotope protection despite increasing visitor numbers.

\subsection{Geoparks}

At the end of the 1990s, the four initiators, being Lesvos Petrified Forest (Greece), Réserve géologique Haute Provence (France), Maestrazgo Cultural Park (Spain), and Gerolstein/Vulkaneifel (FRG), financed by the EU funding program LEADER, had initiated the Geopark movement. The objectives were the protection of their geological and geomorphological heritage and the promotion of a sustainable regional development [42]. In 2000, the European Geoparks Network (EGN) was established. Geoparks are not conservation areas according to law, but are regions with outstanding geological and geomorphological heritage, as well as a strategy for sustainable regional development, environmental education, and scientific research. Clearly defined boundaries and economic development potential are required. In addition to the geopotentials, archaeological, ecological, and cultural sites should be connected in the network. Since geoheritage is the crucial basis, geoparks must ensure its preservation [35]. Geoparks are key areas for geotourism [4].

As early as 2001, European Geoparks had signed an agreement with UNESCO, which placed the network under its auspices. At the end of 2015, the UNESCO Global Geoparks (UGGps) formed a further category of UNESCO sites in addition to World Heritage Sites, Natural World Heritage Sites, and Biosphere Reserves [43]. The UNESCO Global Geoparks are to function as model regions for sustainable development [44]. In doing so, they should enable both inhabitants and visitors to get to know and appreciate the values of the region, and thus build up regional awareness. As innovation regions, they should reconcile conservation and economic development needs [45]. The UNESCO program has stimulated numerous countries to create corresponding development strategies [46]. The Geopark movement has seen pronounced momentum over the last two decades. Currently, $161 \mathrm{UN}-$ ESCO Global Geoparks exist in 44 countries, with 81 of them in 26 European countries.

Due to the increasing interest in geo topics and the international movement, the BLAGEO (Bund-Länder-Ausschuss Bodenforschung) established the quality label "National Geopark" for Germany. In 2002, the Alfred Wegener Foundation awarded this title to the first four German geoparks [47]. In the meantime, there are 17 National geoparks in the Federal Republic of Germany, including seven also designated as European and UNESCO Global Geoparks.

\subsection{Geoconservation}

Although the earliest nature conservation concerned geotopes (including the Pierre à Bot erratic boulder at Neuchâtel, Switzerland, which was protected as early as 1838 [39] or the Drachenfels as the oldest nature reserve in Germany), geotope protection is still the "stepchild of nature conservation" today $[11,20]$. While the protection of biodiversity has been largely uncontroversial, at least since the relevant agreement came into force in 1992, the protection of geodiversity was considered less relevant because, among other things, threats were not as obvious as for biodiversity [48]. "There is an urgent need to accentuate 
the principle that natural diversity is composed of both geodiversity and biodiversity, and that proficient conservation requires a holistic approach that views nature as a complex interaction of biodiversity and geodiversity pattern and process" [49]. As early as 2001, it has been suggested that geodiversity should be placed on an equal footing with biodiversity, and that both should be considered under the umbrella term of ecodiversity [50].

On an international level, the attitude toward geotope protection started to improve with the beginning of the Geopark movement, where geotope protection is an implicit goal. Meanwhile, the IUCN changed its definition of protected areas to integrate abiotic factors and presented comprehensive guidelines for geotope protection in 2020 [51]. As geoparks have no legal means of their own to ensure the protection of geopotentials [13], they must ensure it by other means such as geo-education [52].

In Germany, however, this rethinking process is still at an early stage [20]. Even the current version of the Federal Nature Conservation Act neither includes the term 'geotope' nor 'geotope protection'. While (cultural) landscape and soils are listed as "worthy of protection for safeguarding the landscape's recreational value as well as the ecosystem", important elements of our earth's history are not automatically protected by law [53]. Geotopes are therefore only protected if, due to their habitat function, they can be classified as biotopes worthy of protection according to $\S 30$ of federal law. This applies, for example, to rocky and steep coasts. Geotopes may be also protected, if they are designated as natural monuments due to "their scarcity, special character or outstanding beauty" (§ 23 federal law) or if geoparks are located within large-scale protected areas, which applies to the majority of German geoparks [54]. There are no plans, however, to protect all geotopes. Only those geotopes "distinguished by their special geological significance, rarity, intrinsic nature or beauty and are of particular value for science, research and teaching and for natural and cultural history" will enjoy special protection [53].

\subsection{Geo-Education}

Due to the lack of knowledge of geological and geomorphological processes and formations, as well as the diverse values of geomorphosites, appropriate educational programs are urgently required $[52,55]$. However, geology has taken a rather subordinate position in educational activities in Germany for a long time. A survey of educational nature trails in the federal republic showed that from a total of 660 trails analysed, only c. 20 i.e., 3\% dealt with geology as a subject area [56]. Similarly, geology is underrepresented in the German school curriculum. Whereas biology as a school subject is featured prominently at all stages, geological and geomorphological topics are only covered occasionally, and in no great depth, in geography lessons. In Germany, geology does not exist as an independent school subject. This is further aggravated by the fact that, as a school subject, geography receives only little attention in the curriculum; in recent years, the situation has been further exacerbated, and some schools do not cover it at all or teach it only in so far as it is relevant for human geography.

This began to change at the end of the 1990s following the designation of the first geoparks. European geoparks have to support environmental education for the wider public, and therefore develop educational methods to explain their geological heritage [35]. In the Year of Geosciences 2002, Germany introduced the so-called "day of the geotope". Since then, it has been repeated annually on the third Sunday of September and has contributed decisively to an enhanced public awareness of geotopes [57]. The International Year of Planet Earth further increased the visibility of geosciences. Multi-faceted activities enhanced awareness of geoheritage for both policy makers and the public [58].

\section{Methodology}

Our article draws upon extensive published research on geo- and archaeological diversity, especially within our study region. For an initial assessment of geotourism potential, we used the comprehensive mapping of geotopes [57,59-61] of Baden-Württemberg as a basis. The mapping of biotopes [62] provides supplementary information, since in Ger- 
many geotopes that provide habitat functions for animals and plants, such as caves or calcareous tufa cascades, are often listed as biotopes. Since the mapping was accomplished some time ago, from 2000 to 2007, we verified the current condition of high-value geotopes through our own surveys in the field. In 2017, a management concept for outstanding geotopes within the UNESCO Global Geopark Swabian Alb was published [63]. Again, we verified the mapping as well as the current condition of high-value geotopes through our own fieldwork.

In summer 2021, we conducted a SWOT analysis of the UNESCO Global Geopark Swabian Alb at Rottenburg University of Applied Forest Sciences. We analysed the current strengths, as well as weaknesses, of the geopark. Furthermore, the working group discussed opportunities and threats. In addition to literature research and fieldwork, we conducted numerous interviews with tourism stakeholders such as the Tourism Association Swabian $\mathrm{Alb}$ and the Tourism Department, and Geopark managers including the UNESCO Global Geopark Swabian Alb headquarters and GeoUnion Alfred Wegener Stiftung. The SWOT analysis also included extensive observations of developments during the COVID-19 pandemic. Especially for this purpose, search engines (particularly Google) were used to search for relevant articles in local newspapers (keywords: 'Corona', 'COVID 19' , 'overtourism', 'impairments', 'visitor rush', etc.). Additionally, four interviews with a total of seven specialists (local and regional tourism stakeholders, headquarters of German National Geoparks and UNESCO Global Geopark Swabian Alb), as well as an online survey with a total of ten representatives of the counties within the UGG Swabian Alb, were conducted.

In addition, this study is broadened by my two decades of first-hand experience as a scientist, landscape guide, and vice chairwoman of the advisory board of the UNESCO Geopark Swabian Alb.

\section{Case Study of Baden-Württemberg}

We show the current challenges of valorizing outstanding geo- and archaeological diversity using the case study of the southwest German state of Baden-Württemberg. We will first describe the regional geo-, bio-, and archaeological diversity (Section 4.1) of a region that is the second most important tourist destination in Germany (Section 4.2), followed by the regional historical development of geotourism until now, including the impact of the COVID-19 pandemic (Section 4.3). After a short SWOT analysis (Section 4.4), our review concludes with specific challenges and possible strategies to overcome these challenges (Section 4.5).

\subsection{Outstanding Geodiversity}

Baden-Württemberg offers outstanding geodiversity. On a relatively small area of $280 \mathrm{~km}$ by $210 \mathrm{~km}$, nearly one billion years of earth history unfolds (see Figure 1) [23-26].

The geological map of southwest Germany shows four large units with different dates of origin. The crystalline basement is built up by igneous and metamorphic rocks of Paleozoic age. The overburden consists of a wide variety of sediments, ranging from Permian to Jura. A large part of Baden-Württemberg is a cuesta landscape, composed of Triassic, as well as Jurassic, sediment layers. Through the inclination of these layers due to the alpine orogeny and the formation of the Upper Rhine Rift Valley, a "classic example of an almost undisturbed cuesta landscape" [26] could have formed. Beside the Katzenbuckel volcano, the highest elevation in Geopark Bergstraße-Odenwald, there are no Cretaceous deposits in southwest Germany [25]. During the Tertiary, volcanic phenomena were observed in several places in what is now Baden-Württemberg. This was the case in the Rhine Rift Valley, particularly the Kaiserstuhl, the Hegau volcanoes west of Lake Constance and the Urach-Kirchheim volcanic area (Swabian Alb) (see Figure 1). Volcanism, which reappeared for the first time since the Permian, relates to the intensification of tectonic processes during Alpine orogeny and the formation of the Rhine Rift Valley. The Swabian Volcano (UNESCO Global Geopark Swabian Alb), with 360 mapped volcanic vents and an area of $1600 \mathrm{~km}^{2}$, is one of the most important tuff vent areas on Earth [65]. The Upper 
Rhine Rift Valley is filled with massive sediment deposits, mainly from the Pleistocene. Substantial molasses layers cover the alpine foothills. The Ice Ages shaped Lake Constance and its surroundings extensively during the Pleistocene. Deposits in floodplains, tufa, and sinter formations, as well as recent landslides, occurred during the Holocene (Figure 2).

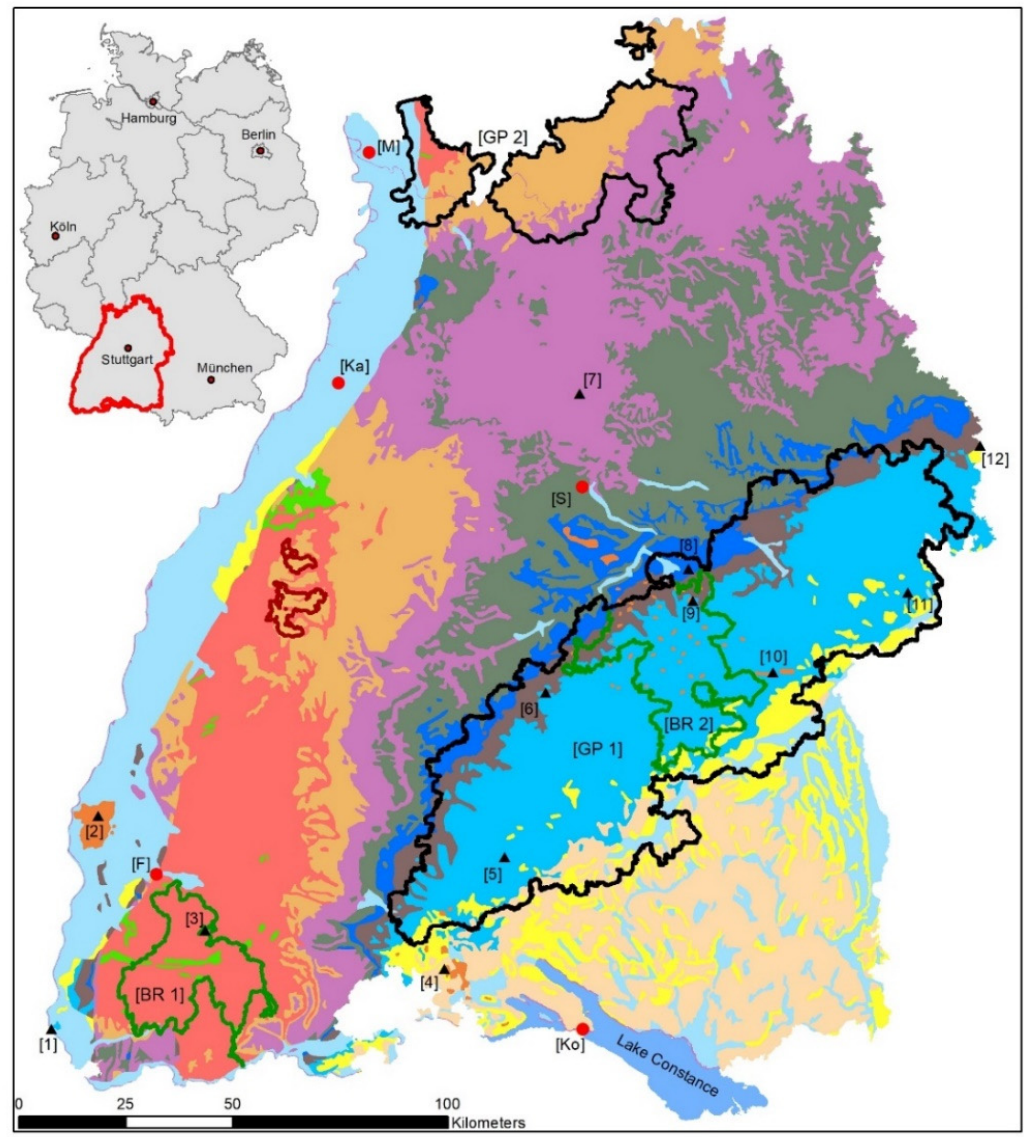

\section{Geological Map of Baden-Württemberg}

\begin{tabular}{l|l} 
Quaternary Gravel & Lower Jurassic \\
Tertiary and Quaternary Deposits & Keuper \\
Tertiary Magmatites & Muschelkalk \\
Moraine Materials & Buntsandstein \\
Upper Jurassic & Paleozoic Deposits \\
Middle Jurassic & Bedrock \\
\hline National Park "Black Forest" & \\
\hline
\end{tabular}

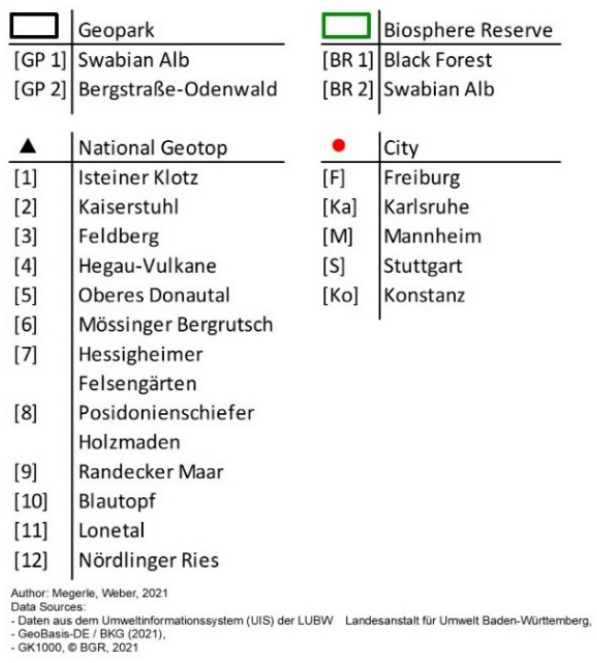

Figure 1. Geological map of Baden-Württemberg with protected areas and National Geotopes (Author's Design; Data Source [64]). For National Geotopes, see Table 1.

The Swabian Alb is the largest karst area in Central Europe with more than 2800 documented caves in the region, and with the highest cave concentration in Germany. These caves played a crucial role during the Aurignacian. The oldest figurative works of art known (Lion Man and Venus from the Hohle Fels cave), as well as the oldest musical instrument, were found here [66]. Southwest Germany is of global importance for geologists due to the two meteor craters (Nördlinger Ries and Steinheimer Becken), world-famous fossil sites (e.g., Holzmaden), the exploration of Jurassic stratigraphy by Friedrich-August von Quenstedt and of the Ice Ages by Albrecht Penck, and finally the archeological sites of Homo heidelbergensis and steinheimensis $[25,26]$. It is especially renowned because of the geological, paleontological, and archaeological highlights listed below: 


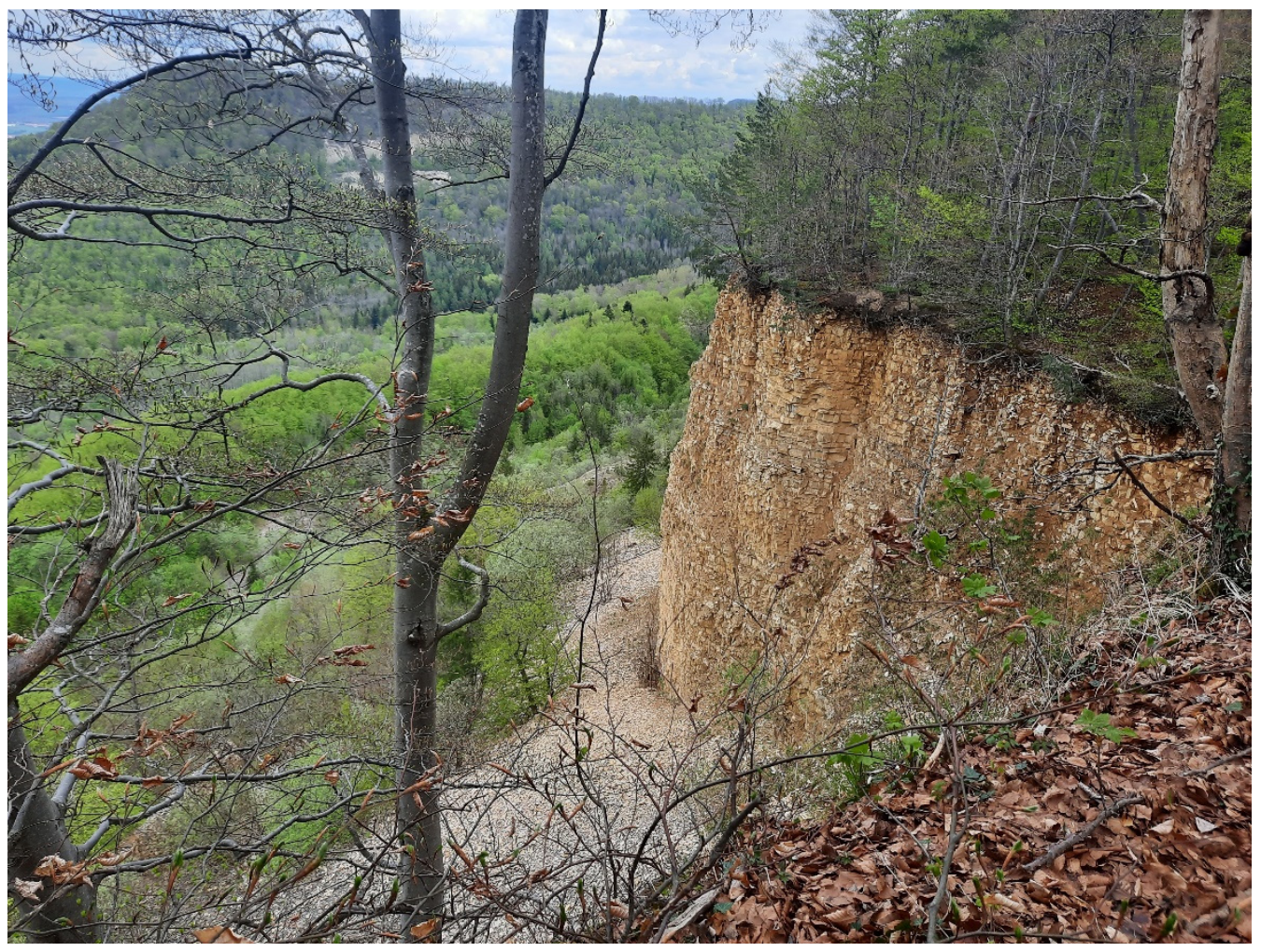

Figure 2. Landslide Mössingen (Author 2021).

\subsubsection{World-Class Fossil Sites}

Fossil site Holzmaden: Posidonia slate was mined in the quarries near Holzmaden. The site became world famous through the discovery of completely preserved ichthyosaur skeletons, partly with skin remains and embryos, a crinoid colony of $18 \mathrm{~m}^{2}$, and other outstanding paleontological discoveries.

Fossil site Nusplingen: In the Nusplingen plate limestones, more than 350 plant and animal species of the Jurassic period were found in exceptionally good preservation, including sea-crocodiles, pterosaurs, giant dragonflies, and the ray-like sharks that became known as sea angels [67].

Fossil site Höwenegg (Figure 3): The Höwenegg belongs to the Hegau volcanoes. In the maar sediments, formed in the crater area, sensational mammal fossils could be unearthed, including the three-toed prehistoric horse Hipparion as well as antelopes, saber-toothed tigers, giant sloths, and the Deinotherium giganteum, an extinct genus of proboscideans $[26,65]$.

Fossil site Öhningen at Lake Constance: The site boasts perfectly preserved fossils of fish, amphibia, and reptiles. Worth noting in particular is the giant salamander Andrias scheuchzeri. The Zurich physician Jakob Scheuchzer interpreted the fossil in 1726 as the skeletal remains of a "poor sinner" drowned in the deluge [68].

\subsubsection{World-Class Archaeological Sites}

Mauer near Heidelberg: Here, the lower jaw of Homo heidelbergensis has been discovered in a sand pit. With an estimated age of about 600,000 years, this is the oldest fossil of the genus Homo in Germany [69].

Steinheim an der Murr: At this site, the skull of Homo steinheimensis (younger female about 300,000 years old) has been unearthed in a gravel pit in 1933 [26].

Caves and Ice Age Art in the Swabian Jura: Since 2017, the caves in the Ach and Lone valleys are UNESCO World Heritage sites. Outstanding finds include 33,000- to 43,000 -year-old carved figures, jewelry, and musical instruments. They are among the 
oldest evidence of figurative art and the world's oldest musical instruments found to date [70].

\subsubsection{National Geotopes}

In 2004, the Academy of Geosciences launched a Germany-wide competition to award the most important geotopes of the Federal Republic of Germany as so-called National Geotopes. From 180 submitted proposals, 77 National Geotopes were selected [71]. A subsequent nomination followed in 2019. Baden-Württemberg hosts 12 National Geotopes (see Table 1).

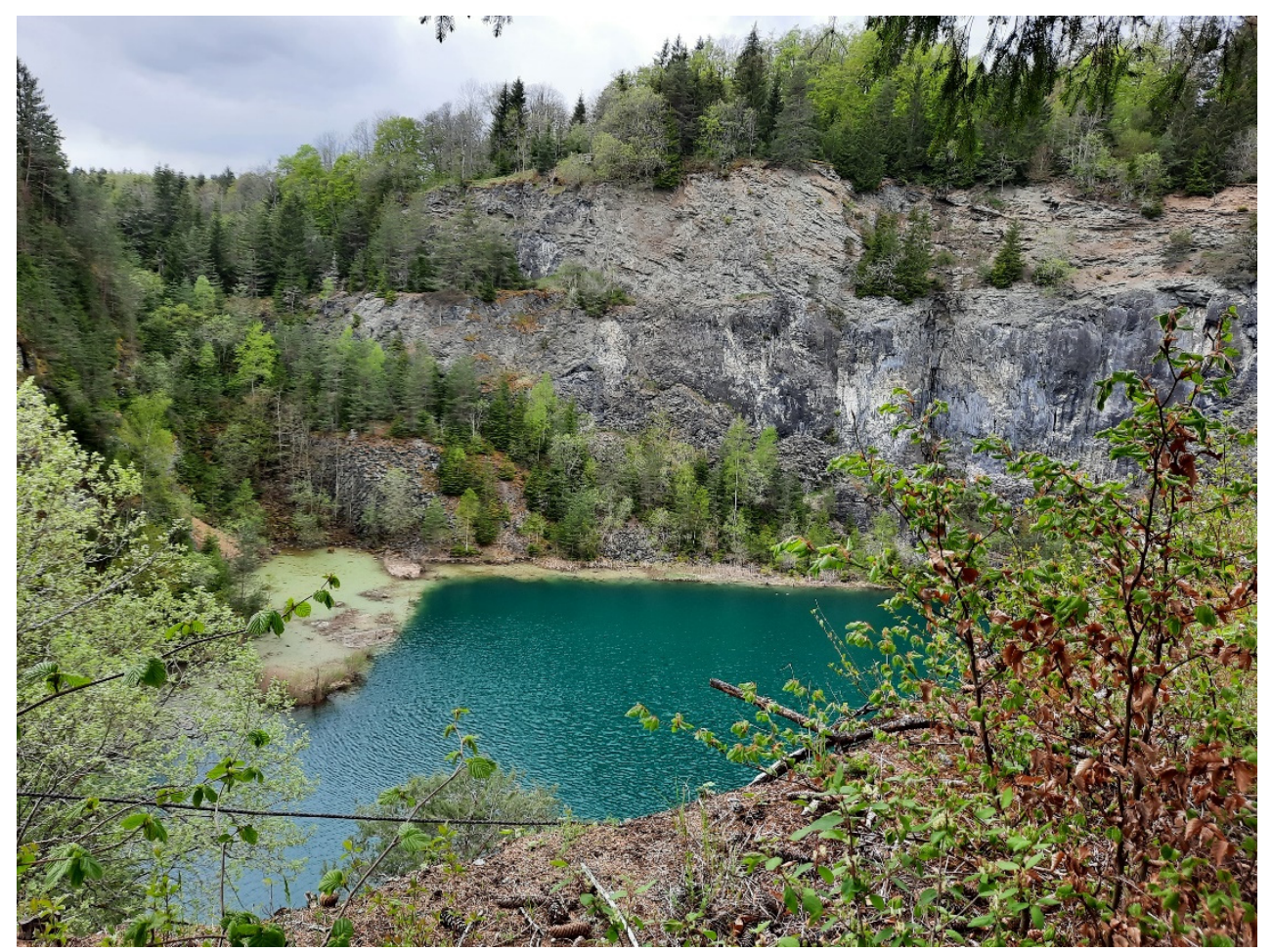

Figure 3. Fossil site Höwenegg (Author 2021).

\subsubsection{National Natural Monuments}

Since 2010, the German Nature Conservation Act includes the new category of National Natural Monument. Following category III of the IUCN, nationally significant geologicalgeomorphological phenomena can also be included. Currently, such a designation is being discussed both for the Danube valley, which is of national importance as a large-scale geotope and also because of its archaeologically significant caves and numerous castles, and the Danube seepage area. In the latter, almost the entire water flow of the Danube seeps into the underlying karst rocks on almost two hundred days a year. 
Table 1. National Geotopes in Baden-Württemberg (Author's design). (Geographical location see Figure 1).

\begin{tabular}{|c|c|c|c|c|}
\hline National Geotop & $\mathrm{Nr}$ & Geological Form & $\begin{array}{l}\text { Geotouristic } \\
\text { Valorization }\end{array}$ & Other Remarks \\
\hline Kaiserstuhl & 1 & Miocene volcanism & $\begin{array}{l}\text { Nature center and } \\
\text { numerous nature trails, } \\
\text { but focus mainly on the } \\
\text { special fauna and flora }\end{array}$ & $\begin{array}{c}\text { First description of plutonic } \\
\text { rocks, e.g., Mondhaldeit or } \\
\text { Bergalit [71] } \\
\text { Viticulture since Roman times }\end{array}$ \\
\hline Randecker Maar & 2 & $\begin{array}{l}\text { Miocene volcanism; } \\
\text { Maar, Part of } \\
\text { Swabian Volcano }\end{array}$ & $\begin{array}{l}\text { Nature conservation } \\
\text { center with exhibition; } \\
\text { Various Geopoints } \\
\text { and tours }\end{array}$ & $\begin{array}{l}\text { International importance as } \\
\text { fossil site and for } \\
\text { bird migration }\end{array}$ \\
\hline Hegau-Vulkane & 3 & $\begin{array}{l}\text { Tertiary volcanism } \\
\text { Basalt- and Phonolith } \\
\text { cones }\end{array}$ & $\begin{array}{l}\text { Volcano trail } \\
\text { Volcano tours }\end{array}$ & $\begin{array}{l}\text { Fossil site Höwenegg of } \\
\text { worldwide significance } \\
\text { (Figure 3). Numerous castles } \\
\text { on the hilltops. }\end{array}$ \\
\hline $\begin{array}{c}\text { Feldberg and } \\
\text { Wutachschlucht (Gorge of } \\
\text { river Wutach) }\end{array}$ & 4 & $\begin{array}{l}\text { Highest mountain in } \\
\text { Germany outside } \\
\text { the Alps. } \\
\text { Paleozoic gneisses; } \\
\text { Gorge system: } \\
\text { 60-170 m deep and } \\
33 \mathrm{~km} \text { long }\end{array}$ & $\begin{array}{l}\text { Several sites where } \\
\text { important fossil have } \\
\text { been found; } \\
\text { nature trails }\end{array}$ & $\begin{array}{l}\text { Highly frequented tourism } \\
\text { destination; Feldberg also a } \\
\text { popular destination for } \\
\text { winter sports }\end{array}$ \\
\hline $\begin{array}{l}\text { Holzmaden Possidonia } \\
\text { slates }\end{array}$ & 5 & See Section 4.1 .1 & $\begin{array}{l}\text { Museum; fossil } \\
\text { discovery sites }\end{array}$ & $\begin{array}{l}\text { Global significance as a } \\
\text { fossil site }\end{array}$ \\
\hline Upper Danube Valley & 6 & $\begin{array}{l}\text { Breakthrough valley } \\
\text { with numerous Jurassic } \\
\text { rock outcrops (Figure 4) }\end{array}$ & $\begin{array}{l}\text { Numerous hiking and } \\
\text { biking trails }\end{array}$ & $\begin{array}{c}\text { Part of the international } \\
\text { Danube Cycle Path. Stone Age } \\
\text { caves and medieval castles }\end{array}$ \\
\hline $\begin{array}{l}\text { Blaubeurener Alb with } \\
\text { Blautopf (carstic spring) }\end{array}$ & 7 & $\begin{array}{l}\text { Second-richest spring } \\
\text { discharge in Germany, } \\
\text { connected with an } \\
\text { extensive cave system }\end{array}$ & $\begin{array}{l}\text { Information boards; } \\
\text { museum of prehistory } \\
\text { at Blaubeuren }\end{array}$ & $\begin{array}{c}\text { Numerous sagas and legends } \\
\text { about the beautiful karst } \\
\text { spring Blautopf }\end{array}$ \\
\hline $\begin{array}{l}\text { Lonetal (Valley of } \\
\text { river Lone) }\end{array}$ & 8 & $\begin{array}{c}\text { UNESCO World } \\
\text { Heritage site (see } \\
\text { Section 4.1.2) One of } \\
\text { the longest dry valleys } \\
\text { in Germany }\end{array}$ & $\begin{array}{l}\text { Archaeological } \\
\text { theme park }\end{array}$ & $\begin{array}{l}\text { Outstanding Stone Age } \\
\text { artworks (Lion Man) }\end{array}$ \\
\hline Isteiner Klotz & 9 & $\begin{array}{l}\text { Huge Jurassic rock in } \\
\text { the Rhine Rift Valley }\end{array}$ & $3 \mathrm{~km}$ long circular trail & Castle in a spectacular location. \\
\hline Hessigheimer Felsengärten & 10 & $\begin{array}{l}\text { Rock formation in } \\
\text { above the } \\
\text { Neckar valley }\end{array}$ & Hiking trails & Very popular climbing area \\
\hline Mössinger Bergrutsch & 11 & $\begin{array}{l}\text { Extensive landslide on } \\
\text { Jurassic cuesta } \\
\text { (see Figure 2) }\end{array}$ & $\begin{array}{l}\text { Nature trail with } \\
\text { information panels }\end{array}$ & $\begin{array}{l}\text { Outdoor Laboratory of the } \\
\text { University of Tübingen }\end{array}$ \\
\hline $\begin{array}{c}\text { Nördlinger Ries (mostly } \\
\text { located in Bavaria) }\end{array}$ & 12 & Meteor crater (Tertiary) & $\begin{array}{l}\text { Geopark Ries with } \\
\text { nature trails etc. }\end{array}$ & $\begin{array}{l}\text { Little "sister" (small meteor } \\
\text { crater) in the Steinheim Basin } \\
\text { (Baden-Württemberg) }\end{array}$ \\
\hline
\end{tabular}




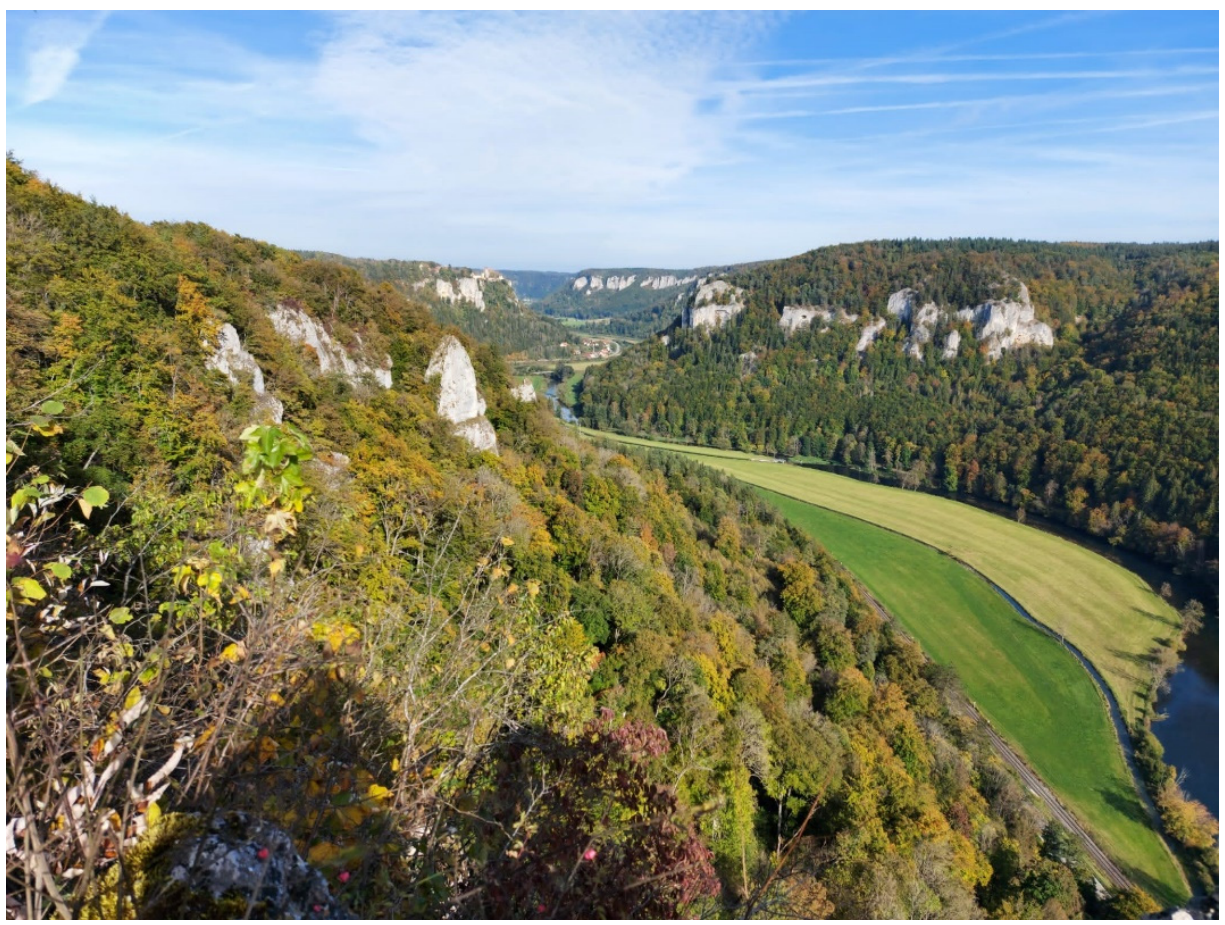

Figure 4. Danube valley in Baden-Württemberg (Martin Holland 2020).

\subsubsection{UNESCO Global Geoparks, National Parks and Biosphere Reserves}

Numerous protected areas reflect the outstanding geo- and biodiversity of BadenWürttemberg. These include small-scale natural monuments and large-scale nature and landscape conservation areas, as well as seven nature parks. In 2014, Baden-Württemberg nominated its first national park in the northern Black Forest, the first biosphere reserve in the Swabian Alb in 2008, followed by the Southern Black Forest biosphere reserve in 2016. A further biosphere area, "Oberschwaben-Allgäu", is under discussion. The two UNESCO Global Geoparks Bergstraße-Odenwald and Swabian Alb are among the oldest geoparks worldwide (see Section 4.3.1). Figure 5 shows the high ecological value of the Swabian Alb Geopark with more than 4000 protected areas.

\subsection{Important Destination for Tourism and Local Recreation}

Despite the high importance of the industrial sector in the "Autoland Baden-Württemberg" (location of Daimler, Porsche, and Audi, as well as numerous supplier companies) [27], tourism is a central economic factor with a value of $€ 24$ billion to the economy and around 390,000 fulltime jobs [72]. With over 57 million overnight stays, Baden-Württemberg is the second most important tourist destination in the Federal Republic of Germany after Bavaria [29].

The development in recent years has been very positive, with an increase in arrivals of almost 35\% and overnight stays of almost $25 \%$ (period: 2009-2017). In particular, foreign visitors have seen a significant increase, with overnight stays rising by almost $55 \%$, so that they now account for more than one fifth of the total. Nevertheless, Baden-Württemberg is still a region strongly dependent on domestic tourism - a characteristic that proved to be a resilient factor during the COVID-19 pandemic. Nevertheless, there was a significant drop of almost 50\% in arrivals in 2020 [29]. By contrast, local recreation and day trips boomed (see Section 4.3.4).

Due to its scenic and cultural diversity, Baden-Württemberg is a very heterogeneous tourist destination. The widely known Black Forest dominates with a share of almost $40 \%$ of overnight stays [72], followed by the Lake Constance region. Nature tourism and nature-based leisure activities, such as hiking and cycling, are of great importance in BadenWürttemberg [28]. The earlier tourism concept emphasized the outstanding geoheritage and the development prospects, but criticized the previous "touristic underutilization of the 
geoparks and the positioning in the market that does not correspond to the potential" [73]. The actual tourism concept did not even integrate the geoparks in the project group. Geoparks are only mentioned in passing [28].

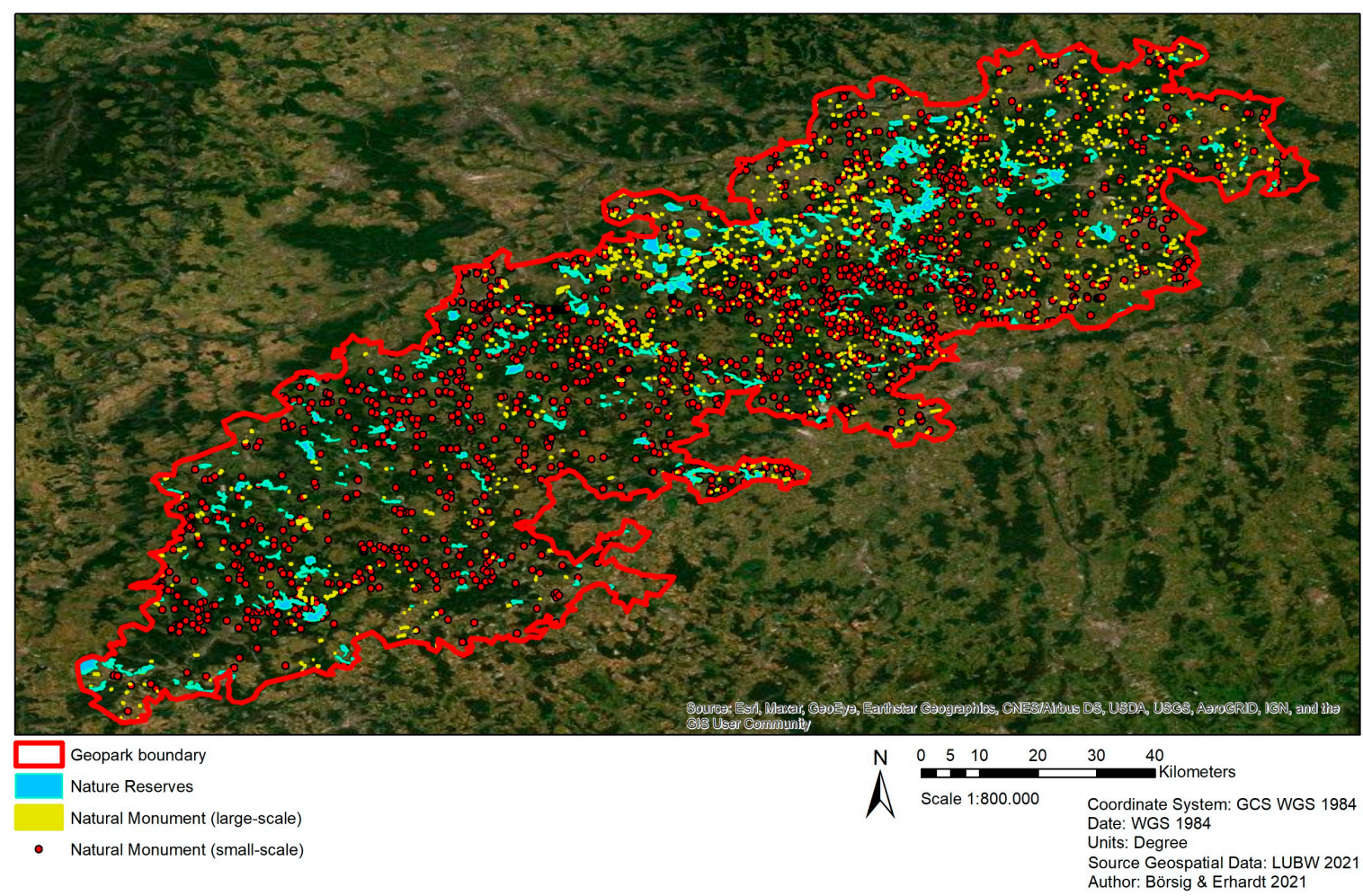

Figure 5. Protected areas in the Swabian Alb Geopark (Design Börsig and Erhardt; Data Source [64]).

\subsection{Geotourism in Baden-Württemberg}

As explained in Section 4.1, Baden-Württemberg, with its diverse geodiversity, has a high potential for geotourism. Nevertheless, the first offers for a lay audience date back only a few decades.

\subsubsection{Historical Development of Geotourism}

As mentioned in Section 4.1, the outstanding geo- and archaeological diversity aroused scientific interest and became known worldwide in the scientific community. Countless scientific publications subsequently dealt with the geoheritage of southwest Germany.

Through hiking clubs like the Schwäbischer Albverein and the Schwarzwaldverein, hikes and excursions to geotouristically interesting destinations were offered early on, and spectacular sites such as the waterfalls near Bad Urach, the numerous caves of the Alb, or the Hegau volcanoes attract many visitors who have no special interest in geology.

The initial starting point of geotourism in southwest Germany coincides with the foundation of the Network Earth History in 1997 by the Chair of Applied Geography at the University of Tübingen in order to valorize the outstanding geodiversity of southwest Germany for sustainable tourism. As a geotourism product package, a 'one billion year journey through the history of the Earth' was on offer [74]. The beginning of geotourism as understood today correlates with the publication of the first edition of the brochure "Adventure Geology" in the year 1999 [75]. The tourism association Swabian Alb initiated the publication of the brochure, which was the first attempt to present geology in a popular publication and in a manner that succeeded in arousing the interest of laypersons. Contrary to the expectations of both the initiators as well as the authors, the brochure sparked phenomenal interest. In the fifth edition, information about the newly established geopark was included. This brochure, now in its 11 th edition with well over 100,000 copies printed, 
paved the way for an increased public awareness of geoheritage. Although an evaluation of the impact of this brochure, both in terms of tourist demand and in terms of raising awareness of geotopes, has not been carried out, there is reason to think that the brochure has made an important contribution to the formation of a "geo-awareness". Teachers often request class sets of the brochure in order to integrate geological phenomena into geography or local history lessons.

In 2000, the first German geotourism Symposium took place in Bad Urach (Swabian Alb), where it was decided to establish a Swabian Alb Geopark. In 2002, the Swabian Alb and Bergstraße-Odenwald Geoparks in Baden-Württemberg were nominated European and National Geopark and a new department for geotourism was set up at the State Office for Geology, Raw Materials, and Mining. At the same time, the book "Erlebnis Geologie" (Experience Geology) and a geotourism map with accompanying booklet for the Swabian Alb Geopark [76] as well as for the Black Forest [77] were published. The brochure "Feuer, Eis und Wasser" (Fire, Ice and Water) informed a lay-audience on the geoheritage of the Lake Constance region [78]. In the meantime, both geoparks in Baden-Württemberg are National as well as European and UNESCO Global Geoparks.

\subsubsection{Geotourism in Baden-Württemberg Today}

Geotourism has developed very dynamically since the nomination of the two geoparks almost twenty years ago. A complete overview of today's geotourism offers within Baden-Württemberg is no longer possible, due to the significant increase of tourism offers. Furthermore, the clear distinction of geotourism from related forms of tourism is generally difficult [39]. For these reasons, among others, there are no new editions of the geotourism maps $[76,77]$ to date.

\section{UNESCO Global Geopark Swabian Alb}

In the Swabian Alb Geopark, there are now 28 information points and 35 geopoints (=geological highlights with information panels). It is envisaged to create a total of 100 geopoints, enabling tourists to travel through earth history. A discovery map (Entdeckerkarte) was published in 2021 in print and online, listing 70 geotourism highlights (Figure 6).

Probably the most effective means of communicating geotopics to the public are landscape guides, for whom a special training program exists since 2001. Since 2015, geology and soils are part of the curriculum. Since 2017, the Geopark has been integrated into the nationwide network of environmental education centers (BANU). Despite the positive development, there are still some shortcomings (see Section 4.3.3).

\section{UNESCO Global Geopark Bergstraße-Odenwald}

The Bergstraße-Odenwald Geo-Nature Park is a cross-border park with areas in the states of Baden-Württemberg, Hesse, and Bavaria. It integrates a total of 13 information centers, five environmental education stations, numerous nature trails, and guided tours [80].

\section{Regions Outside Geoparks}

In the subregions of Baden-Württemberg that lie outside the two geoparks, there are also numerous geotourism activities on offer, ranging from nature and adventure trails to guided tours to museums and information centers. Particularly noteworthy are the Hegau volcanoes and the Black Forest National Park, as well as the state's second biosphere area in the Southern Black Forest. 


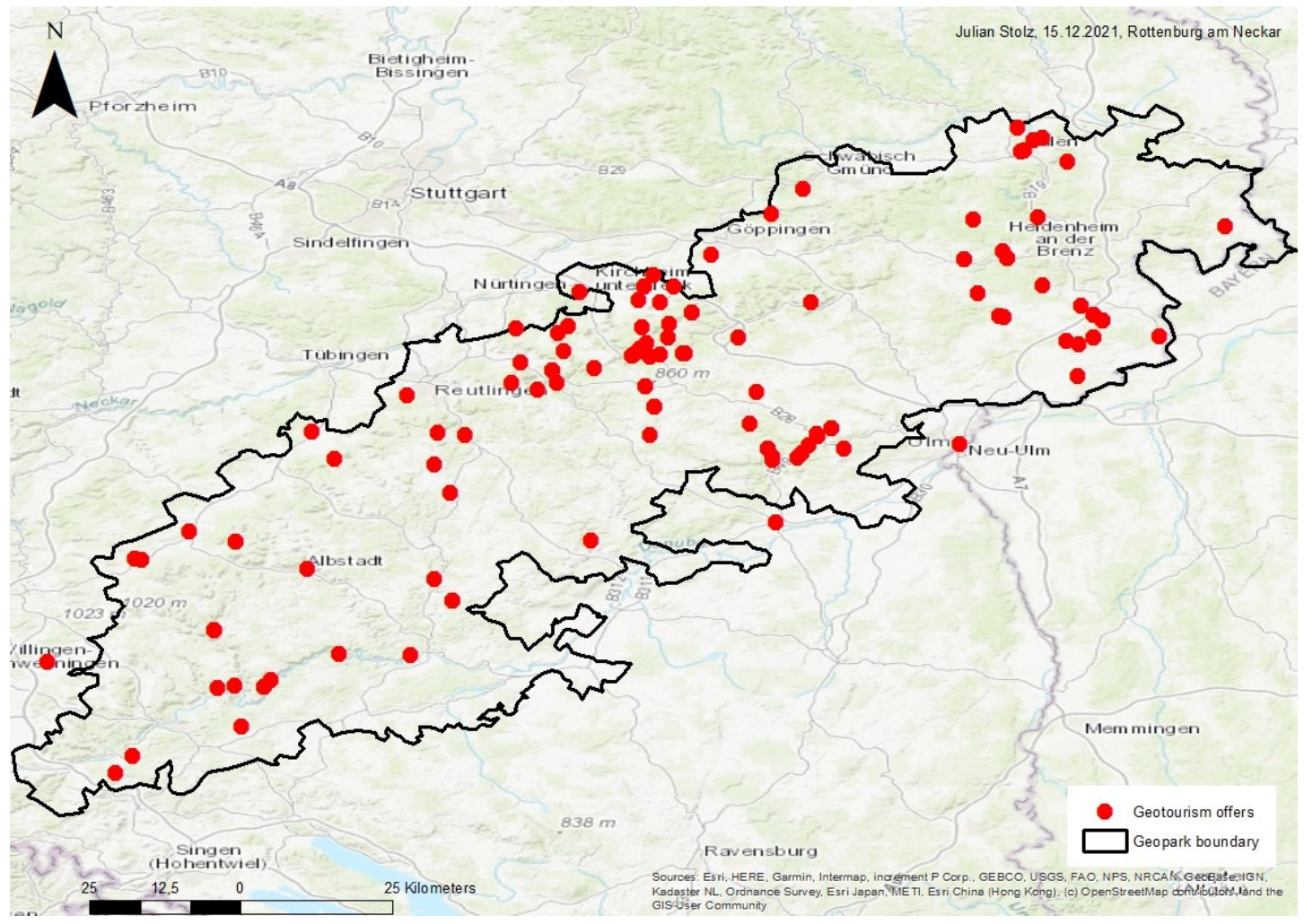

Figure 6. Highlighted points of interest on the discovery map of the UNESCO Global Geopark Schwäbische Alb (Design Julian Stolz, Data Source [79]).

\subsubsection{Shortcomings in Geo-Education and Geoconservation}

Although geotourism has developed very positively overall, there is still a need for action. The former tourism concept of the state of Baden-Württemberg criticized the "touristic underuse of the geoparks and the positioning in the market that does not correspond to the potential" [68]. Until today, the Geopark Swabian Alb has the problem that few members of the public are aware of its existence, especially in comparison to the biosphere areas and the Northern Black Forest National Park. A survey revealed that the term geopark was unknown to three quarters of those questioned, whereas most people knew of nature reserves and half of them also knew about the Biosphere reserves [81]. On the one hand, this is due to the numerous tourism stakeholders in the Swabian Alb, who do not always act in a supportive and cooperative manner, and, on the other hand, due to the vast expanse of more than $6000 \mathrm{~km}^{2}$ managed by a small office. The situation is aggravated by the "parochial thinking" of the diverse regional and local actors, who are only responsible for small areas and are critical of geotopics, which are seen as "unwieldy and difficult" [82]. The organization of tourism institutions is in need of much reform. There are redundancies, duplications, and unnecessary competition [28]. Efforts on public relations and on improving the experience for visitors, including large information panels at all entrance points, ensured that biosphere reserves received much greater publicity within a short time than the considerably older geopark [54]. One reason for the insufficient cooperation might be different responsibilities, as well as different means of funding. Seventy percent of the finances for the biosphere reserves are from the state of BadenWürttemberg and 30\% from the communities involved [83]. The geopark is financed mostly by membership fees. Normally, state-financed projects have to respect strict limits as to the allocation and use of resources.

In addition to the above-mentioned problems, there are still significant shortcomings in valorizing outstanding geoheritage like the "Swabian volcano" [84]. On relevant homepages, caves and fossil sites are promoted as interesting places to visit, and volcanic 
landforms are featured only as a subcategory. In the special "Geoparks" issue of the journal Bild der Wissenschaft, the geopark presents itself as the "Jurassic Park in Germany". In the five-page summary, the volcanic geoheritage is not even mentioned once, and no volcanic landform appears among the highlights listed [85]. This also applies to the illustrated book Vulkane, Schluchten und Höhlen [86], in which the Swabian Alb is likewise reduced to fossils, strata, and meteorite craters. Of the current 35 geopoints, which are supposed to represent a selection of the geotourism highlights, only three are volcanic landforms (Höwenegg volcanic crater (Figure 3) and the Neuffen and Aichelberg volcanic vents). The 39 outstanding geotopes presented on the homepage include only four geotopes of volcanic origin. In addition to the three geopoints mentioned above, these include the internationally important Randecker Maar and the neighbouring Schopflocher Moor. Of the 22 nature trails listed on the homepage, only one (Volcano crater circular trail—Vulkankraterrundweg Münsingen-Apfelstetten) deals with volcanic heritage. Of the 24 listed guided tours, not a single one valorizes volcanic geoheritage. Even for the guided tours of the Nature Conservation Center Schopfloch, in direct vicinity of the outstanding volcanic landforms Randecker Maar and Schopflocher Moor, the term "volcanism" is not mentioned at all. This applies also to the 42 listed museums as well as the official map of the geopark. The geopark cooperates with schools and offers support for school trips and excursions. Special educational material on volcanic geoheritage is, however, not yet available. Volcanic landforms, such as the weathered volcanic vents in the Alb's foothills, are mostly without any information boards on site that explain the volcanic formation to visitors. This applies among others to the Georgenberg, a striking hilltop on the outskirts of the city of Reutlingen with a viewpoint that attracts numerous visitors as well as the Calver Bühl (Figure 7). This would be an ideal opportunity to draw attention to a Swabian volcano.

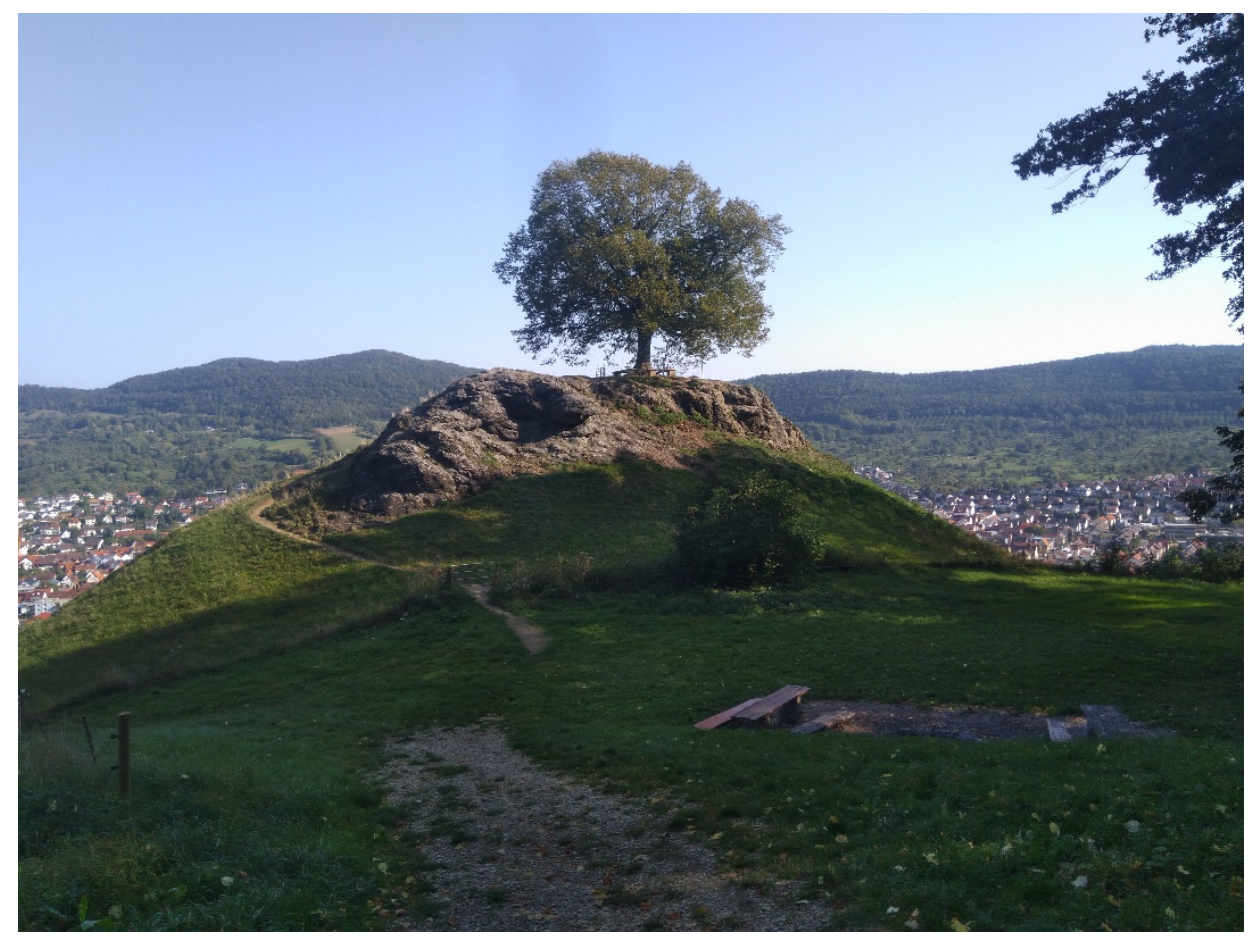

Figure 7. Volcanic vent Calver Bühl (Author 2020).

In 2003, the geotourism map for the National Geopark Swabian Alb was published [76]. This map, supplemented by a detailed booklet, lists geotourism destinations including museums, educational and adventure trails, nature conservation centers, and selected geotopes. For each geotope listed, the booklet contains information on the location, accessibility, and geological features. Of the 38 listed museums, only one deals in passing with volcanic geoheritage; of 19 nature trails, the proportion is also very low: only one. Of 
79 listed out-crops, eight are of volcanic origin, and of 83 landforms only four are identified as being from volcanic origin [76]. The selection seems somewhat arbitrary. Some volcanic landforms are mentioned, others are omitted. Contrary to the geotourism map for the Black Forest [77], published one year later, there is no general information about the geopark's geology. A keyword search is therefore not possible. The short scientific texts make it even more difficult for laypeople to use the map. For the outstanding geopoint "Höwenegg", for example, only the Miocene basalt tuff is mentioned. A reader who is not familiar with the technical terminology may completely overlook the volcanic formation. The combination of didactically inadequate texts with incorrect assignments is particularly problematic. Sternberg's nature trail does not take into account any of the required criteria for a professional heritage interpretation (see Section 4.5) and the one panel for a volcanic vent was unfortunately set up in front of dolomite rock [87]. In 2003, the popular hiking guide "Vulkanalb" [88] was published. Sixteen thematic hiking trails allow recreational visitors to discover the geoheritage. A new and updated edition appeared in 2016. Numerous other hiking guides also integrate volcanic phenomena, but contrary to [88] only as one aspect among many others. The particularly striking volcanic formations are mostly integrated, especially the Randecker Maar. This also applies to geological field guides, which usually include some excursions. In contrast to the hiking guides, these books (e.g., [89,90]) are aimed more at a professional audience. A comprehensive strategy for the geotouristic valorization of the Tertiary volcanic phenomena does not yet exist in the geopark Swabian Alb. In the foreseeable future, the signage of further volcanic geopoints is planned: Randecker Maar, Calver Bühl, and the Hüle (village pond) in Zainingen (Figure 8), which points to the great importance of water impermeable volcanic rocks for the settlement development on the karstified Alb. Due to COVID-19 restrictions, several geopoint awards already planned for 2020 have been postponed. This also concerns the planned exhibition "Otto Mäusnest-Erforscher des Schwäbischen Vulkans" (Otto Mäusnest-Reseacher of the Swabian Volcano), which was to open in spring 2020 at the Biosphere center.

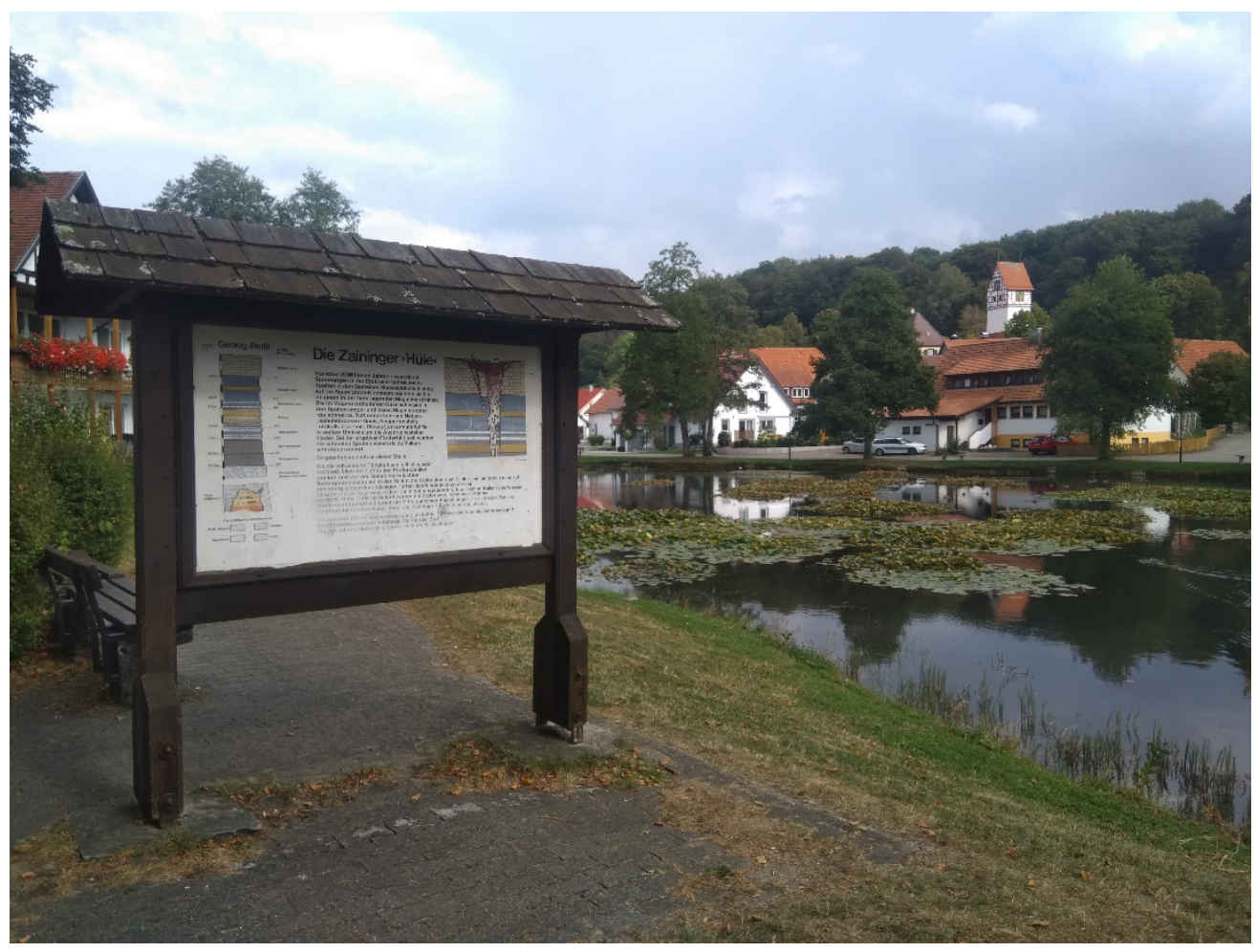

Figure 8. Village pond in Zainingen on water impermeable volcanic rocks (Author 2020). 
In addition to volcanic landforms, there should also be a greater focus on volcanic fossil sites. Some of these are of international importance (i.e., the Randecker Maar, Böttingen quarry, and Höwenegg) and could reach other target groups. In the longer term, the Swabian volcano is to be included in the "Route to the Volcanoes of Germany" [91]. As volcano geotourism is still underdeveloped in the Geopark Swabian Alb, sharing experience and learning about good practice is particularly important. Examples from other German Geoparks like Vulkaneifel or Bayern-Böhmen could be very helpful, as well as strategies applied successfully at regions abroad, like the "Land of Extinct Volcanoes" in Poland, the Bohemian Paradise (Czechia), Novohrad/Nógrád (Slovakia, Hungary), and BakonyBalaton (Hungary) [92,93].

In general, the distribution of geotourism programmes is far from even, as can be seen in Figure 9. Therefore, efforts should be focused on neglected areas within the geopark.

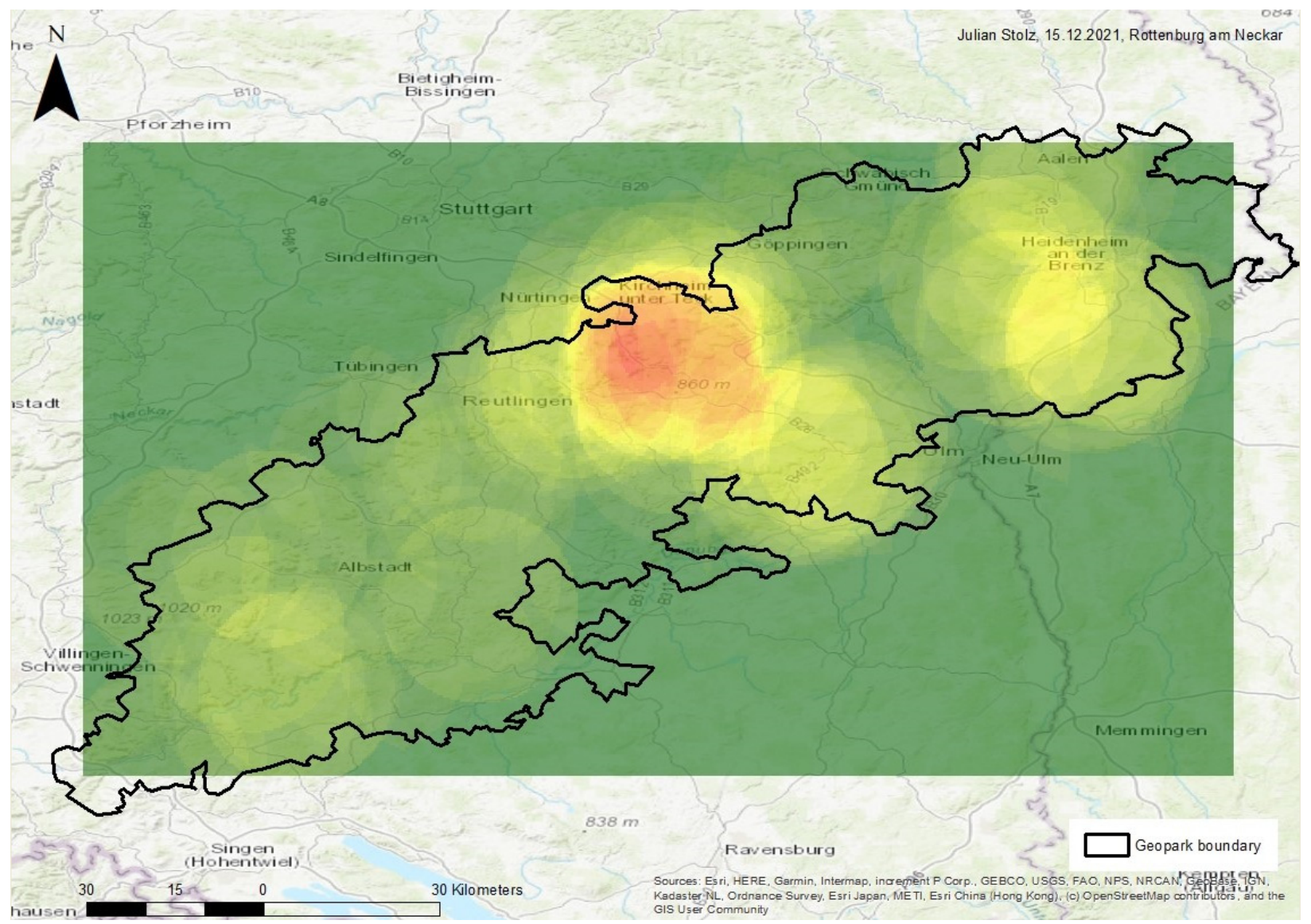

Figure 9. Heatmap of geotourism offers of the UNESCO Global Geopark Swabian Alb (Julian Stolz).

The SWOT analysis also revealed that some of the geotourism offers advertised on the Geopark's website had not been maintained in the field and were thus severely degraded. In general, many nature trails within the geopark did not meet recent environmental education standards. They rarely integrate interactive or interpretive elements and are predominantly traditional. The geopark's outdated website is also in urgent need of revision and updating, as in its present form, it neither attracts visitors nor raises awareness of the importance of the geological heritage.

\subsubsection{Geotope Protection, a Stepchild of Nature Conservation}

To this day, there is much divergence between geotope and biotope conservation in Germany (see Section 2.4). A survey of natural monuments in Baden-Württemberg showed that $89 \%$ were biotopes and only $11 \%$ were geotopes. Even the responsible Ministry of the 
Environment [94] concedes that there are "legal deficits in geotope protection". A comprehensive mapping of geotopes worthy of protection in Baden-Württemberg [57,59-61] showed that only some of these geotopes enjoy a protected status (Figure 10). Depending on the type of geotope, the ratio varies greatly. While for geomorphological forms and karst phenomena, the majority of the recorded geotopes are protected, far fewer fossil sites and important stratigraphic sequences benefit from protected status.

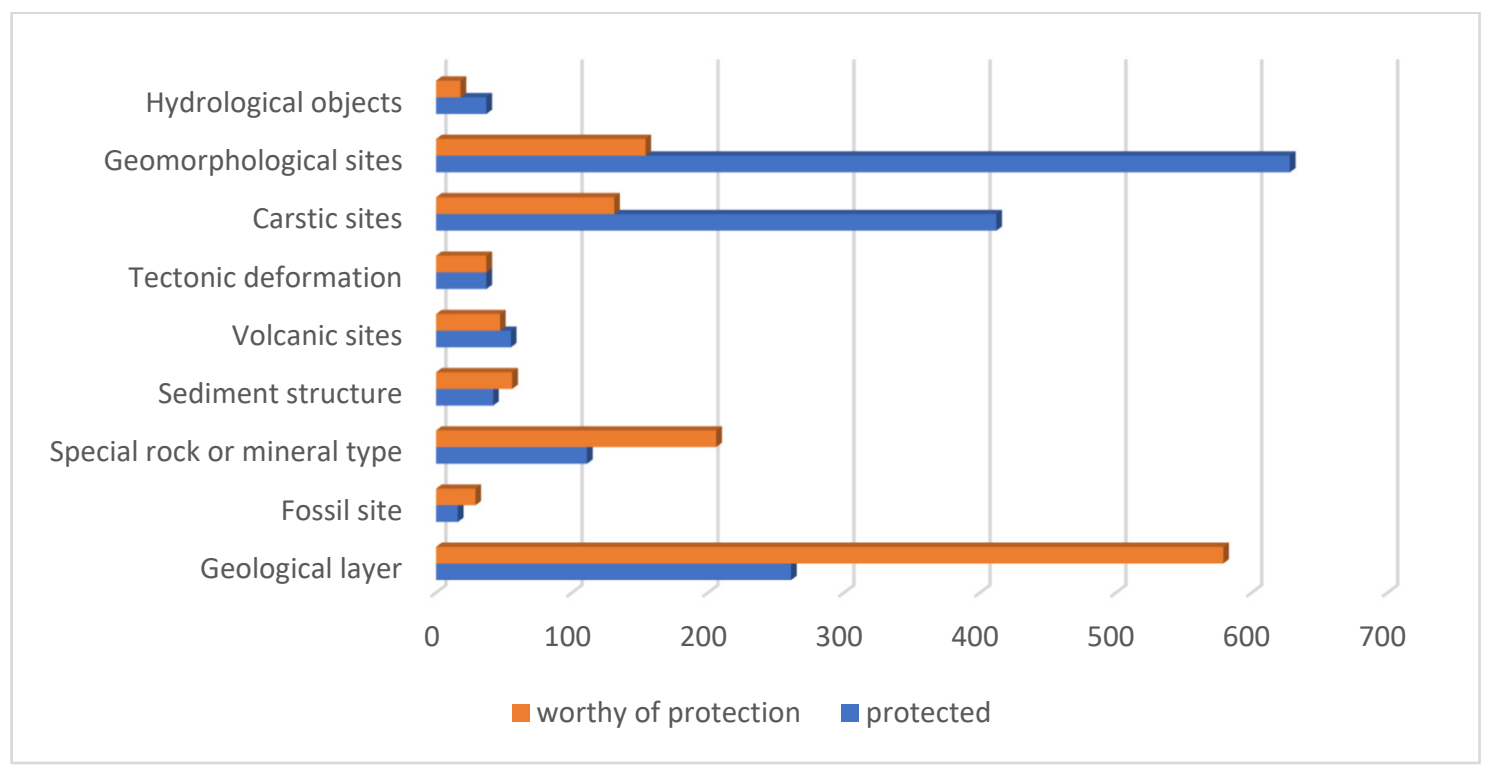

Figure 10. Ratio of geotope types judged worthy of protection and protected geotopes in BadenWürttemberg (Author's design; Data Sources [57,59-61]).

In 2017, a geotope management concept for the Geopark Swabian Alb Geopark was published and is a decisive instrument to ensure the compatibility of geotope protection and geotourism [63]. Geotopes protected by law (natural monument, nature reserve, etc.) can only be integrated in touristic activities if it does not compromise their preservation [63].

Within the geopark network, the touristic use of fossil discovery sites is highly controversial. In general, taking out fossils or minerals from geoparks is forbidden. However, miners and other private companies offer access to several fossil discovery sites in the UNESCO Global Geopark, as they are popular, especially for families with children. As all these sites are located at spoil heaps of mining areas, and they are accessible only under supervision and normally contain predominantly worthless fossils and fool's gold (pyrite), tourist activities are acceptable even under the Geopark's regulations.

The damage to sensitive geotopes (including caves and calcareous tufa) by excessive visitor numbers and/or inadequate behavior is far more problematic. A prime example is the Urach Waterfall, one of the most famous attractions of the UNESCO Global Geopark Swabian Alb. For quite some time, the excessive numbers of visitors, who seriously affect the very sensitive calcareous tufa formations by improper behavior, has caused considerable problems [95]. This has worsened dramatically during the COVID-19 pandemic. Severe restrictions on travel abroad, as well as on numerous other leisure activities, have led to a rediscovery of the surrounding homeland ('Heimat'). The number of visitors to local natural areas for recreation, walking, cycling, and hiking not only increased significantly, but also meant that parts of the population that had not previously frequented local attractions in the countryside have discovered natural sites at their doorstep [96]. This not only increased the absolute number of visitors, but also the number of people who are either unaware of, or even indifferent to, appropriate behavior in nature. Due to the much-increased pressure, some sensitive natural areas have suffered considerably. Severe measures, such as barring all visitor access (Figure 11), had to be implemented at some sites. 


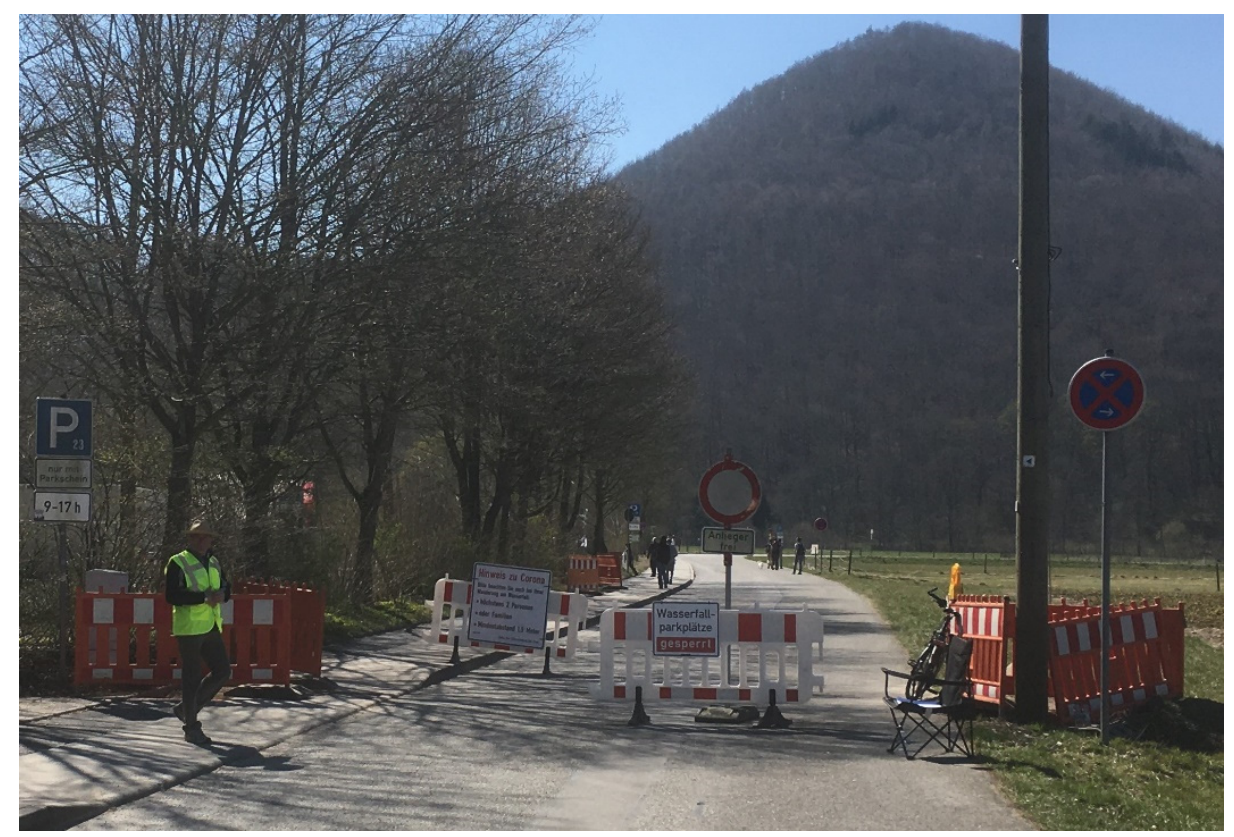

Figure 11. Barring access to geosites during COVID-19 pandemic within the Geopark Swabian Alb (Mall 2020).

In particular, vulnerable tufa landforms have been adversely affected. During the first lockdown in spring 2020, there were 'mass migrations' on the access roads to, and in the immediate vicinity of, the Urach waterfall, especially on weekends and times of good weather (Figure 12). Parking spaces soon ran out of capacity and hundreds of cars parked along the farm tracks and in nearby meadows. At the peak period, more than 2000 cars were counted daily. Trampling damage increased. The authorities closed both the awardwinning hiking trail and the majority of car parks. The police were on duty on horseback around the waterfall [96]. After the situation had temporarily calmed down over the summer, visitor numbers surged again in the course of the second lockdown in November 2020. Yet, on this occasion, neither barriers were installed nor did the police take action. The city merely appealed to the common sense of visitors. During the third lockdown around Easter Holiday 2021, new car parks were opened. Other parts of Baden-Württemberg reported similar developments.

\subsection{SWOT-Analysis of Geotourism in Baden-Württemberg}

As shown above, Baden-Württemberg offers outstanding geodiversity, which so far is insufficiently valorized for sustainable geotourism.

Table 2 compares strengths, weaknesses, opportunities, and threats of geotourism in Baden-Württemberg.

\subsection{Recommended Strategies for Action and Solutions}

As explained above, the valorization of the outstanding geodiversity in Baden-Württemberg still shows significant weaknesses. We recommend the following strategies:

Geotourism as part of the state's tourism strategy: As explained in Section 4.2, representatives of the geoparks were not involved in the development of the tourism concept. Geotourism must become a field of action of the state tourism association as well as of subordinate levels in order to guarantee an adequate valorization. We recommend developing and implementing a comprehensive concept for sustainable geotourism, taking into account the points mentioned below. 


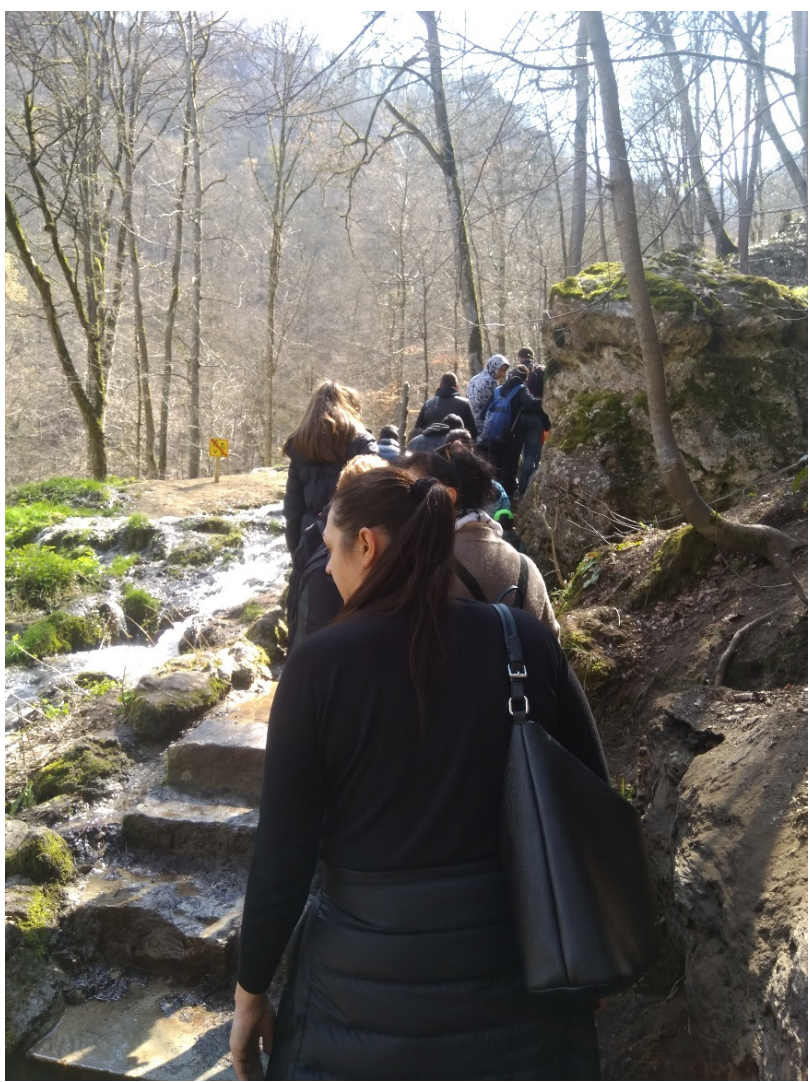

Figure 12. Visitor rush at the Urach waterfall (Author 2021).

Table 2. SWOT analysis of geotourism in Baden-Württemberg.

\section{Strengths}

Opportunities

- $\quad$ El Dorado for scientists

- Diverse offers for different target groups possible

- Possibility of complementary offers for diversification

- $\quad$ Outstanding geodiversity

- High diversity of different geotopes and geolandscapes in a small area

- $\quad$ One billion years of earth history
- High demand for tourism and recreation due to densely populated metropolitan regions in close proximity to geolandscapes

- High demand due to high educational attainment and economic potential of the population

- Popular region for outdoor activities with very active hiking and cycling clubs

\begin{tabular}{lll}
\hline Weaknesses & \multicolumn{2}{l}{ Threats } \\
\hline - $\quad \begin{array}{l}\text { Valorization of geoheritage still } \\
\text { insufficient }\end{array}$ & - $\begin{array}{l}\text { Competitive situation and lack of } \\
\text { cooperation between key stakeholders }\end{array}$ \\
- Low awareness level of UNESCO Global & - $\begin{array}{l}\text { Insufficient geotope protection at least in } \\
\text { seopark Swabian Alb }\end{array}$ \\
$\begin{array}{l}\text { Populations lacks knowledge in } \\
\text { geosciences, therefore arousing of interest } \\
\text { essential. }\end{array}$ & - $\begin{array}{l}\text { Local overtourism, especially during } \\
\text { COVID-19 pandemic, threatens the } \\
\text { geoheritage }\end{array}$ \\
\end{tabular}


Inventory: The inventory for the geotourism maps [76,77] is almost twenty years old; the statewide surveys of geotopes worthy of protection were carried out between 2000 and 2007 [57,59-61]. An update is indispensable, especially since geotourism has developed very dynamically in the last two decades.

Assessment and evaluation: An updated inventory must necessarily be combined with a reassessment of the geoscientific value of the mapped geotopes and geolandscapes, as well as the quality of geotourism offers. There are still offers, such as traditional nature trails, which no longer comply with modern didactic approaches.

Geotope protection: As explained in Section 2.4, the geotope protection in BadenWürttemberg still shows considerable deficiencies. Therefore, it is necessary to record the current state, as well as the degree of endangerment, of the mapped geotopes and geolandscapes. Based on scientifically sound criteria (e.g., [97,98]), the integration of respective geotopes into geotourism offers has to be examined. Furthermore, a geoconservation concept has to be developed to ensure the preservation of high-value geotopes and geolandscapes.

Geo-education: Since many problems of unsustainable geotourism, but also the partial lack of demand for geotourism offers, are due to knowledge gaps, we recommend an improvement of geo-education. Therefore, a methodological approach of heritage interpretation is advisable [99-102]. We recommend further training courses for all stakeholders.

Cooperation of different stakeholders: Instead of parochialism and competition, the cooperation of the different stakeholders (municipalities, tourism associations, large protected areas, geoparks, etc.) should be strengthened and the win-win situation for all involved should be demonstrated.

Financial support: The recommended inventory, as well as the geotourism concept and training courses for geo-education, require a great deal of personnel and time. This can neither be done by the responsible authorities, nor by the corresponding associations (tourism association, geoparks, etc.), in addition to their normal workload. Financial support (e.g., European programs like LEADER) is indispensable.

Regular evaluation: After the realization of sustainable geotourism offers, an evaluation at regular intervals has to be guaranteed in order to recognize undesirable developments on time and to be able to take countermeasures, but also to be able to react to unexpected current developments (e.g., the rush of visitors during the COVID-19 pandemic).

\section{Discussion}

According to previous work [44], UGGps are "some of the best territories in the world to establish and continually improve sustainable development strategies". UGGps represent a successful path to global sustainability by fostering the economic sustainable development of host regions through the promotion of geotourism and geo-education [37,38]. Thereby, the goals of sustainable geotourism are geoconservation, high-quality geotourism, benefits for the host communities, and raising awareness [36].

Our surveys clearly show that southwest Germany has an outstanding geoheritage that can form the basis for sustainable geotourism as previously defined [44]. Complementary to regional added value, geo-awareness can be raised by educational programs. However, it is crucial to ensure adequate geoconservation to avoid endangering geotopes, especially in periods of high visitor numbers as seen during the COVID-19 pandemic.

Our surveys are consistent with observations in other geo- and nature parks. In particular, geoheritage perceived as spectacular is increasingly valorized and visited by tourists. In regions with active volcanism, volcanoes are among the "primary drawcards for visitors" [103-105]. A destination like Iceland, which specifically markets its spectacular geolandscapes (island of fire and water), recorded one of the world's strongest increases in international visitors. While there were just 460,000 in 2010, this number rose to 2.3 million by 2018 , with $92 \%$ of international visitors to Iceland citing natural potential as a travel motivation [106]. 
Extinct volcanism is considered to play only a secondary role [105] and must be combined with other attractions to increase the number and length of stay of visitors. However, these volcanic forms are also a characteristic part of the regional geoheritage and, as such, are worthy of protection and should be considered important components of geotourism offers [104]. In Germany, the two geoparks in the Eifel region market the "adventure volcanism" intensively. Even non-specialists perceive the Eifel as the "land of maars, geysers and dormant volcanoes" [86]. In the meantime, however, numerous other regions are also staging their geopotentials of extinct volcanism [84].

Numerous other studies corroborate our investigations and point to a serious impairment of geotopes, especially of the very sensitive calcareous tufa formations [16-18,21,22,107-113].

Geotourism destinations have recorded increasing visitor numbers in recent years (see above). Iceland, which is in high demand, was therefore one of the few nature destinations where one could speak of overtourism, even before the COVID-19 pandemic [114]. The "rediscovery of home" during the COVID-19 pandemic led to considerable overtourism via day trips, with negative repercussions. This phenomenon has also been observed nationally and internationally. Not only the Geopark, but also other protected areas, faced challenges [31], some of them seeing a two-fold increase in visitor numbers. All protected areas reported overcrowding (mainly caused by domestic visitors), problems related to motorised traffic (e.g., an increase in volume and parking in non-designated areas), problematic behavior (e.g., littering, pollution through dog/human waste, noise nuisance, and illegal/unauthorized activities), and conflicts between visitors and local residents, mostly as a result of overcrowding and trespassing on to private property [32,115].

Likewise, the need for adequate geotope protection measures, nationally and internationally, is evident to preserve geologic heritage [116-119].

\section{Conclusions}

Our surveys have shown that:

1. Southwest Germany has an outstanding geological and archaeological heritage.

2. This heritage forms a sound basis for sustainable geotourism.

3. To date, the valorization of geological and archaeological heritage is still insufficient, despite the area boasting two of the oldest German geoparks.

Therefore, the following strategies should be developed:

1. Better marketing in combination with professional geo-education.

2. Adequate geoconservation, especially in highly frequented areas.

Perspectives of future research are:

1. New challenges for geotourism and geoconservation, especially during the COVID-19 pandemic.

2. Strategies of resilience, especially for the "World After" [44] and in the context of climate change.

3. How to best define and to implement sustainable geotourism.

Funding: The article processing charge was funded by the Baden-Württemberg Ministry of Science, Research and Culture and the University of Applied Forest Sciences at Rottenburg via the funding program Open Access Publishing.

Institutional Review Board Statement: Not applicable.

Informed Consent Statement: Not applicable.

Data Availability Statement: Not applicable.

Acknowledgments: The author is very grateful to Markus Weber for his valuable support for the geological map included in this article, to Pia Stockburger for helping with the translation, to Alan Bryan for reviewing the English text, to Eberhard Sauer for language polishing, to Julian Stolz, Nico Börsig, and Lisa Erhardt for permission to reproduce their maps, and to Martin Holland and Bernd 
Mall for their consent to publish their photos. The author is also grateful to the three anonymous reviewers for their helpful suggestions.

Conflicts of Interest: The author declares no conflict of interest.

\section{References}

1. Hose, T. Geotourism-Appreciating the deep time of landscapes. In Niche Tourism, Contemporary Issues, Trends and Cases; Novelli, M., Ed.; Routledge: London, UK, 2004; pp. 27-37.

2. Dowling, R.; Newsome, D. Handbook of Geotourism; Edward Elgar Publishing: Northampton, MA, USA, 2018; ISBN 10-1785368869.

3. Dowling, R.; Newsome, D. Geotourism; Routledge: Amsterdam, The Netherlands, 2010; ISBN 978-1906884093.

4. Newsome, D.; Dowling, R. Geoheritage and Geotourism. In Geoheritage: Assessment, Protection, and Management; Reynard, E., Brilha, J., Eds.; Elsevier: Amsterdam, The Netherlands, 2018; pp. 305-321; ISBN 9780128095317.

5. Reynard, E.; Brilha, J. (Eds.) Geoheritage: Assessment, Protection, and Management; Elsevier: Amsterdam, The Netherlands, 2018; ISBN 9780128095317.

6. Chen, A.; Lu, Y.; Ng, Y.C.Y. The Principles of Geotourism; Springer: Berlin/Heidelberg, Germany, 2015; ISBN 978-3-662-46696-4.

7. Reynard, E.; Coratza, P. Geomorphosites; Friedrich-Pfeil-Verlag: Munich, Germany, 2009; ISBN 978-3899370942.

8. Megerle, H. Geotourismus_Versuch Einer Definitorischen Eingrenzung In Geotourismus Innovative Ansätze zur Touristischen Inwertsetzung und Nachhaltigen Regionalentwicklung; Megerle, H., Ed.; Kersting: Rottenburg am Neckar, Germany, 2008; pp. 21-27; ISBN 3-937559-09-4.

9. Olafsdottir, R. Geotourism. Geosciences 2019, 9, 48. [CrossRef]

10. Singh, R.B.; Wei, D.; Anash, S. (Eds.) Global Geographic Heritage, Geoparks and Geotourism. Geoconservation and Development; Advances in Geographical and Environmental Sciences; Springer: Singapore, 2020; ISBN 978-981-15-4955-7.

11. Gray, M. Geodiversity. Valuing and Conserving Abiotic Nature, 2nd ed.; Wiley-Blackwell: Chennai, India, 2013; ISBN 978-0470742143.

12. Hopfinger, H. Geographie der Freizeit und des Tourismus. In Geographie: Physische Geographie und Humangeographie; Gebhardt, H., Glaser, R., Radtke, U., Reuber, P., Eds.; Spektrum Akademischer: Heidelberg, Germany, 2011; pp. 1041-1043; ISBN 978-3-8274-2816-5.

13. Brilha, J. Geoheritage: Inventories and evaluation. In Geoheritage: Assessment, Protection and Management; Reynard, E., Brilha, J., Eds.; Elsevier: Amsterdam, The Netherlands, 2018; pp. 69-86.

14. Vorlaufer, K. Karst und Tourismus. Geogr. Rundsch. 2005, 57, 34-43.

15. Migon, P. Development of karst phenomena for geotourism in the Moravian Karst (Czech Republic). Geotourism 2011, 3-4, 26-27.

16. Antić, A.; Tomić, N.; Marković, S. Karst Geoheritage and Geotourism Potential in the Pek River Lower Basin (Eastern Serbia). Geogr. Pannonica 2019, 23, 32-46. [CrossRef]

17. Šiljeg, A.; Marić, I.; Cukrov, N.; Domazetović, F.; Roland, V. Multiscale Framework for Sustainable Management of Tufa-Forming Watercourses: A Case Study of National Park "Krka", Croatia. Water 2020, 12, 3096. [CrossRef]

18. Liu, L. Factors Affecting Tufa Degradation in Jiuzhaigou National Nature Reserve, Sichuan, China. Water 2017, 9, 702. [CrossRef]

19. Pijet-Migon, E.; Migon, P. Promoting and Interpreting Geoheritage at the Local Level-Bottom-Up Approach in the Land of Extinct Volcanoes, Sudetes, SW Poland. Geoheritage 2019, 11, 1227-1236. [CrossRef]

20. Megerle, H.; Pietsch, D. Geotopschutz als Stiefkind des Naturschutzes. Geoparks im Spannungsfeld von Schutz und Nutzung. Nat. Landsch. 2019, 51, 174-182.

21. Gu, Y.; Du, J.; Tang, Y.; Qiao, X.; Bossard, C.; Deng, G. Challenges for sustainable tourism at the Jiuzhaigou World Natural Heritage site in western China. Nat. Resour. Forum 2013, 37, 103-112. [CrossRef]

22. Gračan, D.; Zadel, Z.; Rudančić, A. Management of sustainable tourism development: Case Study Plitvice Lakes National Park. Int. J. Manag. Cases 2011, 13, 24-33. [CrossRef]

23. Meschede, M. Geologie Deutschlands Ein Prozessorientierter Ansatz; Springer-Spektrum: Berlin/Heidelberg, Germany, 2015; ISBN 978-3662452974.

24. Zöller, L. Die Physische Geographie Deutschlands; Wissenschaftliche Buchgesellschaft: Darmstadt, Germany, 2017; ISBN 978-3534268689.

25. Rothe, P. Die Geologie Deutschlands. 48 Landschaften im Portrait, 5th ed.; Wissenschaftliche Buchgesellschaft: Darmstadt, Germany, 2019; ISBN 978-3534271290.

26. Geyer, M.; Nitsch, E.; Simon, T.; Geyer, O.; Gwinner, M. Geologie von Baden-Württemberg, 5th ed.; E. Schweizerbart'sche Verlagsbuchhandlung: Stuttgart, Germany, 2011; ISBN 978-3510652679.

27. Gebhardt, H. Geographie Baden-Württembergs. Raum, Entwicklung, Regionen; Landeszentrale für politische Bildung BadenWürttemberg, Band 36, Schriften zur politischen Landeskunde Baden-Württembergs; Kohlhammer: Stuttgart, Germany, 2008.

28. DWIF Consulting GmbH. Tourismuskonzeption Baden-Württemberg. Available online: https://www.justiz-bw.de/site/pbs-bwrebrush-jum/get/documents_E-473727925/jum1/JuM/TK_Baden-Wuerttemberg-2020_ONLINE.pdf (accessed on 23 June 2021).

29. Erhardt, C. Landestourismus-Quo Vadis? Bilanz des Krisenjahres 2020. Available online: https://www.statistik-bw.de/Service/ Veroeff/Monatshefte/PDF/Beitrag21_05_01.pdf (accessed on 12 November 2021).

30. Skare, M.; Riberio Soriano, D.; Porada-Rochoń, M. Impact of COVID-19 on the travel and tourism industry. Technol. Forecast. Soc. Chang. 2021, 163, 120469. [CrossRef] 
31. McGinlay, J.; Gkoumas, V.; Holtvoeth, J.; Fuertes, R.F.A.; Bazhenova, E.; Benzoni, A.; Botsch, K.; Martel, C.C.; Sánchez, C.C.; Cervera, I.; et al. The Impact of COVID-19 on the Management of European Protected Areas and Policy Implications. Forests 2020, 11, 1214. [CrossRef]

32. Spenceley, A.; McCool, S.; Newsome, D.; Báez, A.; Barborak, J.R.; Blye, C.-J.; Bricker, K.; Cahyadi, H.S.; Corrigan, K.; Halpenny, E.; et al. Tourism in protected and conserved areas amid the covid-19-Pandemic. Parks 2021, 47, 103-118. [CrossRef]

33. Hose, T. 3G's for modern geotourism. Geoheritage 2012, 4, 7-24. [CrossRef]

34. National Geographic. Geotourism. Available online: https://www.nationalgeographic.com/maps/topic/geotourism (accessed on 21 June 2021).

35. European Geoparks Network European Geoparks. Available online: http://www.europeangeoparks.org/ (accessed on 16 September 2020).

36. Dowling, R. The Growth of Global Geotourism. In New Challenges with Geotourism, Proceedings of the VIII European Geoparks Conference, Idanha-a-Nova, Portugal, 14-16 September 2009; Neto de Carvalho, C., Rodrigues, J., Eds.; Printmor Impressores: Idanha-a-Nova, Portugal, 2009; pp. 24-30.

37. Henriques, M.; Brilha, J. UNESCO Global Geoparks: A strategy towards global understanding and sustainability. Episodes 2017, 40, 349-355. [CrossRef]

38. Frey, M.-L. Geotourism-Examining Tools for Sustainable Development. Geosciences 2021, 11, 30. [CrossRef]

39. Reynard, E.; Buckingham, T.; Martin, S.; Regolini, G. Geoheritage, Geoconservation and Geotourism in Switzerland. In Landscapes and Landforms of Switzerland; Reynard, E., Ed.; Springer: Berlin, Germany, 2021; pp. 411-425; ISBN 978-3-030-43203-4.

40. Megerle, H.; Martin, S.; Regolini-Bisig, G. Chancen, Herausforderungen und Risiken der Inwertsetzung des regionalen Geo-Erbes: Geotopschutz und Geotourismus im Spannungsfeld unterschiedlichster Interessen. In Geographica Helvetica in Print; Unpublished paper.

41. Megerle, H. Geotourismus: Ein innovatives Tourismussegment auch für den urbanen Raum. PLANERIN 2018, 6, 27-29.

42. McKeever, P.J.; Zouros, N.C.; Patzak, M. The UNESCO global network of national geoparks. Georg. Wright Forum 2010, 27, 14-18.

43. UNESCO. UNESCO Global Geoparks. Available online: http://www.unesco.org/new/en/natural-sciences/environment/earthsciences/unesco-global-geoparks / (accessed on 2 July 2021).

44. Martini, B.G.; Zouros, N.; Zhang, J.; Jin, X.; Komoo, I.; Border, M.; Watanabe, M.; Frey, M.L.; Rangnes, K.; Van, T.T.; et al. UNESCO Global Geoparcs in the "World After": A multiple-goals roadmap proposal for future discussion. Episodes 2021. [CrossRef]

45. Bétard, F. Géodiversité, Biodiversité et Patrimoines Environnementaux: De la Connaissance à la Conservation et à la Valorization; Mémoire d'Habilitation à Diriger des Recherches; Université Sorbonne Paris Cité: Paris, France, 2017.

46. Girault, Y. Les Géoparcs Mondiaux UNESCO. Une Mise en Tension Entre Développement des Territoires et Mise en Valeur du Patrimoine; ISTE Editions: Surrey, UK, 2019; ISBN 978-1784055622.

47. Geo-Union Alfred Wegener Stiftung Nationaler Geopark. Available online: http://www.nationaler-geopark.de/geopark/ nationale-geoparks / die-16-nationalen-geoparks.html (accessed on 2 October 2020).

48. Crofts, R.; Gordon, J.E. Geoconservation in protected areas. In Protected Areas Governance and Management; Worboys, G., Lockwood, M., Kothari, A., Feary, S., Pulsford, I., Eds.; ANU Press: Canberra, Australia, 2015; pp. 531-568. [CrossRef]

49. Matthews, T.J. Integrating geoconservation and biodiversity conservation: Theoretical foundations and conservation recommendations in a European Union context. Geoheritage 2014, 6, 57-70. [CrossRef]

50. Jedicke, E. Biodiversität, Geodiversität, Ökodiversität. Kriterien zur Analyse der Landschaftsstruktur-ein konzeptioneller Diskussionsbeitrag. Nat. Landsch. 2001, 33, 59-68.

51. Crofts, R.; Gordon, J.E.; Brilha, J.; Gray, M.; Gunn, J.; Larwood, J.; Santucci, V.; Tormey, D.; Worboys, G.L. Guidelines for Geoconservation in Protected and Conserved Areas; Best Practice Protected Area Guidelines Series No. 31; IUCN: Gland, Switzerland, 2020.

52. Henriques, M.H.; dos Reis, R.P.; Brilha, J.; Mota, T. Geoconservation as an Emerging Geoscience. Geoheritage 2011, 3, 117-128. [CrossRef]

53. Bundesamt für Naturschutz. Arbeitsanleitung Geotopschutz in Deutschland; Landwirtschaftsverlag: Münster, Germany, 1996; ISBN 9783896243065.

54. Megerle, H.; Pietsch, D. Consequences of overlapping territories between large scale protection areas and Geoparks in Germany: Opportunities and risks for geoheritage and geotourism. Ann. Géographie 2017, 717, 598-624. [CrossRef]

55. Giusti, C. Introduction to the thematic issue: "From Geosites to Geomorphosites: How to decode the landscape? Geodynamic processes, surficial features and landforms, past and present environments". Géomorphologie 2010, 2, 123-130. [CrossRef]

56. Ebers, S.; Laux, L.; Kochanek, H. Vom Lehrpfad zum Erlebnispfad-Handbuch für Naturerlebnispfade; Naturschutzzentrum Hessen: Wetzlar, Germany, 1998; ISBN 9783926871336.

57. Schöttle, M. Geotope im Regierungsbezirk Tübingen. Available online: https://pudi.lubw.de/detailseite/-/publication/45542 (accessed on 2 October 2020).

58. Cayla, N. Le Patrimoine Géologique de l'arc Alpin, de la Médiation Scientifique à la Valorisation Géotouristique. Ph.D. Dissertation, Presse Universitaire, Chambéry, France, 2009.

59. Burgmeister, G.; Schöttle, M. Geotope im Regierungsbezirk Stuttgart; Kraft-Druck: Ettlingen, Germany, 2002; ISBN 3-88251-283-0.

60. Schöttle, M. Geotope im Regierungsbezirk Freiburg; Greiserdruck: Karlsruhe, Germany, 2005; ISBN 3-88251-293-8.

61. Schöttle, M. Geologische Naturdenkmale im Regierungsbezirk Karlsruhe, 2nd ed.; Präzisdruck: Karlsruhe, Germany, 2000; ISBN 3-88251-079-X. 
62. Landesanstalt für Umwelt Baden-Württemberg. Übersicht Biotoptypen Baden-Württemberg. Available online: https://www. lubw.baden-wuerttemberg.de/natur-und-landschaft/uebersicht-biotoptypen (accessed on 27 September 2021).

63. Pietsch, D.; Huth, T. Geotopmanagementkonzept; Geotopdokumentation 2017; UNESCO Global Geopark Schwäbische Alb: Schelklingen, Germany, 2017.

64. LUBW Daten- und Kartendienst der LUBW. Available online: https://udo.lubw.baden-wuerttemberg.de/public/index.xhtml (accessed on 24 November 2021).

65. Heizmann, E.; Speidel, W. GeoPark Schwäbische Alb-Neue Chancen und Perspektiven für eine Region. In Geotourismus, Innovative Ansätze zur Touristischen Inwertsetzung und Nachhaltigen Regionalentwicklung; Megerle, H., Ed.; Kersting-Verlag: Rottenburg am Neckar, Germany, 2008; pp. 175-184; ISBN 3-937559-09-4.

66. Landesamt für Denkmalpflege im Regierungspräsidium Tübingen. Höhlen der ältesten Eiszeitkunst. Welterbenominierung; Scheufele Druck und Medien: Stuttgart, Germany, 2016; ISBN 978-3942227322.

67. Dietl, G.; Schweigert, G. Im Reich der Meerengel. Der Nusplinger Plattenkalk und seine Fossilien; Pfeil: München, Germany, 2011; ISBN 978-3899371390.

68. Westphal, F. Erster Nachweis des Riesensalamanders (Andrias, Urodela, Amphibia) im europäischen Jungpliozän. In Neues Jahrbuch für Geologie und Paläontologie; Schweizerbart: Stuttgart, Germany, 1967; pp. 67-73.

69. Wagner, G.; Rieder, H.; Zöller, L.; Mick, E. Homo Heidelbergensis. Schlüsselfund der Menschheitsgeschichte; Konrad Theiss Verlag: Stuttgart, Germany, 2007; ISBN 978-3-8062-2113-8.

70. UNESCO. UNESCO-Welterbe Höhlen und Eiszeitkunst der Schwäbischen Alb. Available online: https://www.unesco.de/kulturund-natur/welterbe/welterbe-deutschland/hoehlen-und-eiszeitkunst-der-schwaebischen-alb (accessed on 23 June 2021).

71. Look, E.; Feldmann, L. Faszination Geologie. Die Bedeutendsten Geotope Deutschlands; Schweizerbart: Stuttgart, Germany, 2007; ISBN 978-3510652211.

72. Statistisches Landesamt Baden-Württemberg. Tourismus in Baden-Württemberg Erreicht 2019 Neue Höchstwerte. Available online: https:/ / www.statistik-bw.de/Presse/Pressemitteilungen/2020037 (accessed on 27 September 2021).

73. Burzinski, M.; Lorenz, A.; Springmann, A. Tourismuskonzept Baden-Württemberg; Kohl \& Partner: Stuttgart, Germany, 2009. Available online: https://mlr.baden-wuerttemberg.de/fileadmin/redaktion/m-mlr/intern/dateien/PROJECT_M_ Landestourismuskonzept_Endversion_V29_bebildert_-_Ohne_Vorwort.pdf (accessed on 29 November 2021).

74. Pforr, C.; Megerle, A. Geotourism: A perspective from southwest Germany. In Geotourism; Dowling, R., Newsome, D., Eds.; Routledge: London, UK, 2010; pp. 118-139; ISBN 9780750662154.

75. Hauff, R.; Megerle, A.; Megerle, H.; Dieter, A.; Behmel, H.; Kraus, U.; Klumpp, B. Abenteuer Geologie. Available online: https://www.geopark-alb.de/pdf/Geopark_Broschueren/geopark_imagebroschuere_05_2018_rz_internet.pdf (accessed on 2 October 2020).

76. Huth, T.; Junker, B. Geotouristische Karte Nationaler Geopark Schwäbische Alb mit Umgebung; Reiff Druck: Munich, Germany, 2003.

77. Huth, T.; Junker, B. Geotouristische Karte Schwarzwald mit Umgebung; Reiff Druck: Munich, Germany, 2004; ISBN 3-00-014219-3.

78. Friebe, G.; Heierli, H.; Megerle, H.; Megerle, A.; Zaugg, A. Feuer, Eis und Wasser-Streifzüge durch die Entstehungsgeschichte der Bodenseeregion. Available online: https:/ / de.readkong.com/page/feuer-e-is-und-wasser-9963181 (accessed on 25 November 2021).

79. UNESCO Global Geopark Schwäbische Alb. Available online: https:/ / www.geopark-alb.de/de/ (accessed on 24 November 2021).

80. Geo-Naturpark Bergstraße Odenwald. Available online: http://www.geo-naturpark.net/deutsch/willkommen/kommunen/ neckar-odenwald/waldbrunn.php (accessed on 16 September 2020).

81. Erath, J.; Henkel, S. Gästebefragung auf der Schwäbischen Alb. Master's Thesis, Hochschule, Weingarten, Germany, 2005.

82. Speidel, W. Geopark Swabian Alb; Expert Interview; Münsingen, Germany, 2011.

83. MLR (Ministerium für Ländlichen Raum). Finanzierung und Organisation des Biosphärengebiets Schwäbische Alb in Trockenen Tüchern. Available online: http:/ / www.baden-wuerttemberg.de/de/service/presse/pressemitteilung/pid/finanzierung-undorganisation-des-biosphaerengebiets-schwaebische-alb-in-trockenen-tuechern/ (accessed on 27 September 2021).

84. Megerle, H. Geoheritage and geotourism in regions with extinct volcanism in Germany; Case study southwest Germany with UNESCO Global Geopark Swabian Alb. Geosciences 2020, 10, 445. [CrossRef]

85. Podbregar, N. 15 Nationale Geoparks mit Tollen Touren und Wertvollen Tipps. Bild der Wissenschaft. Spezial Geoparks. Reiseführer Erdgeschichte. Available online: http://www.nationaler-geopark.de/fileadmin/downloads/geoparks/bdw_Geoparks_ Inhalt.pdf (accessed on 2 October 2020).

86. Lauterbach, M.; Kumerics, C. Vulkane, Schluchten, Höhlen. Geologische Naturwunder in Deutschland; Wissenschaftliche Buchgesellschaft: Darmstadt, Germany, 2014; ISBN 978-3806231663.

87. Megerle, H. Naturerlebnispfade-Neue Medien der Umweltbildung und des Landschaftsbezogenen Tourismus? Tübinger Geographische Studien: Tübingen, Germany, 2003; ISBN 9783881210355.

88. Roser, W.; Mauch, J.; Rosenberger, F. Vulkanalb. Unterwegs in der Landschaft des Schwäbischen Vulkans; GO-Verlag: Kirchheim unter Teck, Germany, 2016; ISBN 978-3925589669.

89. Günther, D. Der Schwarzwald und seine Umgebung. Geologie-Mineralogie-Bergbau-Umwelt und Geotourismus; Sammlung geologischer Führer; Band 102. Gebr; Borntraeger: Stuttgart, Germany, 2010; ISBN 978-3443150884.

90. Krafft, M. Führer zu den Vulkanen Europas. Band 2: Deutschland. Frankreich; Ferdinand Enke Verlag: Stuttgart, Germany, 1984; ISBN 978-3827412515. 
91. Abratis, M.; Viereck, L.; Büchner, J.; Tietz, O. Route to the Volcanoes in Germany. Conceptual model for a geotourism project interconnecting geosites of Cenozoic volcanism. Z. Dtsch. Ges. Geowiss. 2015, 2, 161-185. [CrossRef]

92. Migon, P.; Pijet-Migon, E. Overlooked Geomorphological Component of Volcanic Geoheritage-Diversity and Perspectives for Tourism Industry, Pogórze Kaczawskie Region, SW Poland. Geoheritage 2016, 8, 333-350. [CrossRef]

93. Rózycka, M.; Migon, P. Customer-Oriented Evaluation of Geoheritage-On the Example of Volcanic Geosites in the West Sudetes, SW Poland. Geoheritage 2018, 10, 23-37. [CrossRef]

94. Umweltministerium Baden-Württemberg. Geotopschutz und seine rechtlichen Grundlagen in Baden-Württemberg. Available online: http:/ / themenpark-umwelt.baden-wuerttemberg.de/servlet/is / 6277/?path=4422;\&btID=3 (accessed on 20 November 2017).

95. Megerle, H. Les cascades de tuf calcaire près de Bad Urach (Allemagne). Valorisation d'un géotope vulnérable du géoparc mondial de l'UNESCO Schwäbische Alb. In Guide Pratique de Valorisation des Géomorphosites; Ambert, M., Cayla, N., Eds.; Presses universitaires Savoie Mont Blanc: Chambéry, France, 2020; pp. 268-277; ISBN 978-2-37741-046-0.

96. Megerle, H.E. Calcerous Tufa as Invaluable Geotopes Endangered by (over-)Tourism: A Case Study in the UNESCO Global Geopark Swabian Alb, Germany. Geosciences 2021, 11, 198. [CrossRef]

97. Cappadonia, C.; Coratza, P.; Agnesi, V.; Soldati, M. Malta and Sicily Joined by Geoheritage Enhancement and Geotourism within the Framework of Land Management and Development. Geosci. J. 2018, 8, 253. [CrossRef]

98. Selmi, L.; Coratza, P.; Gauci, R.; Soldati, M. Geoheritage as a Tool for Environmental Management: A Case Study in Northern Malta (Central Mediterranean Sea). Resources 2019, 8, 168. [CrossRef]

99. Tilden, F. Interpreting Our Heritage, 3rd ed.; The University of North Carolina Press: Chapel Hill, NC, USA, 1977; ISBN 0-8078-4016-5.

100. Ham, S. Environmental Interpretation-A Practical Guide for People with Big Ideas and Small Budgets; North American Press: Golden, CO, USA, 1992; ISBN 1-55591-902-2.

101. Knudson, D.; Cable, T.; Beck, L. Interpretation of Cultural and Natural Resources; Venture Publishing: Philadelphia, PA, USA, 1995; ISBN 978-0910251709.

102. Brochu, L.; Merriman, T. Personal Interpretation: Connecting Your Audience to Heritage Resources, 3rd ed.; InterpPress: Fort Collins, CO, USA, 2015; ISBN 978-1879931329.

103. Erfurt-Cooper, P. Volcanic Tourist Destinations (Geoheritage, Geoparks and Geotourism); Springer: Berlin/Heidelberg, Germany, 2014; ISBN 978-3642161902.

104. Erfurt-Cooper, P. Active geothermal and volcanic environments as tourist destinations. In Global Geotourism Perspectives; Dowling, R., Newsome, D., Eds.; Goodfellow Publishers: Oxford, UK, 2010; pp. 33-38; ISBN 978-1906884178.

105. Erfurt-Cooper, P.; Cooper, M. Volcano \& Geothermal Tourism. Sustainable Geo-Ressources for Leisure and Recreation; Earthscan: New York, NY, USA, 2010; ISBN 978-1138994119.

106. Óladóttir, O.P. Erlendir Ferðamenn á Íslandi 2018: Lýðfræði, Ferðahegðun og Viðhorf (International Visitors in Iceland 2018. Demography Travel Behaviour and Attitudes); Icelandic Tourist Board: Reykjavík, Iceland, 2019.

107. Qiao, X.; Du, J.; Lugli, S.; Ren, J.; Xiao, W.; Chen, P.; Tang, Y. Are climate warming and enhanced atmospheric deposition of sulfur and nitrogen threatening tufa landscapes in Jiuzhaigou National Nature Reserve, Sichuan, China? Sci. Total Environ. 2016, 562, 724-731. [CrossRef]

108. Pentecost, A. Travertine; Springer: Dordrecht, The Netherlands, 2005; ISBN 978-1402035234.

109. Megerle, H. Cultural values of geomorphosites within the Geopark Swabian Alb In Gestion des géosites dans les espaces protégés; Hoblea, F., Cayla, N., Reynard, E., Eds.; Université Savoie Mont Blanc; Collection EDYTEM, 15; Chambéry, France, $2014 ;$ pp. 149-154.

110. Megerle, H.; Beuter, A. La protection des géotopes et le géotourisme-des intérêts contradictoires ou une préoccupation commune? In Les Géosciences au Service de la Société, Actes du Colloque en L'honneur du Professeur Michel Marthaler; Reynard, E., Laigre, L., Kramar, N., Eds.; Institut de Géographie, Université de Lausanne: Lausanne, Switzerland, 2011; pp. 76-90; ISBN 978-2-940368-12-9.

111. Zhou, X.L. Influences of geological environment deterioration on Jiuzhaigou ravine landscape. Carstologica Sin. 1998, 3, 119-128.

112. Zhang, J.; Wang, H.; Li, D.; Zhao, D. An analysis of travertine landscape degradation in Huanglong Ravine of Sichuan, a world's heritage site, and its causes and protection countermesures. Acta Ecol. Sin. 2012, 1, 111-120.

113. Liu, Z.H.; Tian, Y.P.; An, D.J.; Wang, H.J.; Tang, S.; Zhang, J.L.; Sun, H.; Liu, Y.; Zhang, Q.M. Formation and evolution of the travertine landscape at Huanglong, Sichuan, one of the world natural heritages. Acta Geosci. Sin. 2009, 30, 841-847.

114. Sæpórsdóttir, A.; Hall, C.; Wendt, M. Overtourism in Iceland: Fantasy or Reality? Sustainability 2020, 12, 7375. [CrossRef]

115. Ruede, D. Besuchsaufkommen und Corona. Available online: https://www.nationalpark-schwarzwald.de/fileadmin/ Mediendatenbank_Nationalpark/04_Forschen/Sozialwissenschaftlich/20200805_Besuchsaufkommen_und_Corona_Rueede_ Versand.pdf (accessed on 16 September 2021).

116. Crofts, R. Putting Geoheritage Conservation on All Agendas. Geoheritage 2018, 10, 231-238. [CrossRef]

117. Crofts, R.; Tormey, D.; Gordon, J. Introducing New Guidelines on Geoheritage Conservation in Protected and Conserved Areas. Geoheritage 2021, 13, 33. [CrossRef]

118. Gregorič, A.C. Typical Doline and Surface Landforms of Kras (Slovenia): Karst Landscape Features and Possibilities for Their Conservation. Geoheritage 2021, 13, 26. [CrossRef]

119. Geoheritage in Europe and Its Conservation; Wimbledon, W., Smith-Meyer, S., Eds.; ProGEO: Oslo, Norway, 2012; ISBN 978-82-426-2476-5. 